\title{
Spectral albedo of seasonal snow during intensive melt period at Sodankylä, beyond the Arctic Circle
}

\author{
O. Meinander ${ }^{1}$, S. Kazadzis ${ }^{2}$, A. Arola ${ }^{3}$, A. Riihelä ${ }^{1}$, P. Räisänen ${ }^{1}$, R. Kivi ${ }^{4}$, A. Kontu ${ }^{4}$, R. Kouznetsov ${ }^{1}$, M. Sofiev ${ }^{1}$, \\ J. Svensson ${ }^{1}$, H. Suokanerva ${ }^{4}$, V. Aaltonen ${ }^{1}$, T. Manninen ${ }^{1}$, J.-L. Roujean ${ }^{5}$, and O. Hautecoeur ${ }^{5}$ \\ ${ }^{1}$ Finnish Meteorological Institute, P.O. Box 503, 00101 Helsinki, Finland \\ ${ }^{2}$ Institute for Environmental Research and Sustainable Development, National Observatory of Athens, Greece \\ ${ }^{3}$ Finnish Meteorological Institute, Kuopio Unit, P.O. Box 1627, 70211 Kuopio, Finland \\ ${ }^{4}$ Finnish Meteorological Institute, Arctic Research Centre, Tähteläntie 62, 99600 Sodankylä, Finland \\ ${ }^{5}$ Meteo-France/Centre National de la Recherche Scientifique (CNRS), Toulouse, France
}

Correspondence to: O. Meinander (outi.meinander@fmi.fi)

Received: 17 August 2010 - Published in Atmos. Chem. Phys. Discuss.: 9 November 2010

Revised: 13 March 2013 - Accepted: 13 March 2013 - Published: 10 April 2013

\begin{abstract}
We have measured spectral albedo, as well as ancillary parameters, of seasonal European Arctic snow at Sodankylä, Finland $\left(67^{\circ} 22^{\prime} \mathrm{N}, 26^{\circ} 39^{\prime} \mathrm{E}\right)$. The springtime intensive melt period was observed during the Snow Reflectance Transition Experiment (SNORTEX) in April 2009. The upwelling and downwelling spectral irradiance, measured at 290-550 nm with a double monochromator spectroradiometer, revealed albedo values of $\sim 0.5-0.7$ for the ultraviolet and visible range, both under clear sky and variable cloudiness. During the most intensive snowmelt period of four days, albedo decreased from 0.65 to 0.45 at $330 \mathrm{~nm}$, and from 0.72 to 0.53 at $450 \mathrm{~nm}$. In the literature, the UV and VIS albedo for clean snow are $\sim 0.97-0.99$, consistent with the extremely small absorption coefficient of ice in this spectral region. Our low albedo values were supported by two independent simultaneous broadband albedo measurements, and simulated albedo data. We explain the low albedo values to be due to (i) large snow grain sizes up to $\sim 3 \mathrm{~mm}$ in diameter; (ii) meltwater surrounding the grains and increasing the effective grain size; (iii) absorption caused by impurities in the snow, with concentration of elemental carbon (black carbon) in snow of $87 \mathrm{ppb}$, and organic carbon $2894 \mathrm{ppb}$, at the time of albedo measurements. The high concentrations of carbon, detected by the thermal-optical method, were due to air masses originating from the Kola Peninsula, Russia, where mining and refining industries are located.
\end{abstract}

\section{Introduction}

Snow albedo is a key issue for climate change studies in radiative transfer (RT) calculations and satellite applications. The albedo of a surface results from the target's capability to wavelength-dependently reflect the direct and diffuse irradiance. For snow, the albedo is typically very high compared to other natural objects or surfaces. In the ultraviolet (UV) and visible range (VIS), the albedo for clean snow is 0.97-0.99 (Grenfell et al., 1994; Hudson et al., 2006), consistent with the extremely small absorption coefficient of ice in this spectral region (Wiscombe and Warren, 1980; Warren et al., 2006; Warren and Brandt, 2008). As the wavelength increases, ice absorption increases and masks the absorbing effect of impurities in snow, like black carbon (BC) (Hadley and Kirschtetter, 2012).

The measured albedo is determined by the target's basic properties and the overall environment around the target. According to the literature (Wiscombe and Warren, 1980; Warren and Wiscombe, 1980) and RT models (Flanner et al., 2007; Gardner and Sharp, 2010; Mayer and Kylling, 2005), the effective snow grain size, i.e., grain size and shape distributions, or specific surface area (Domine et al., 2007), is the most important factor to determine snow albedo. According to theory (Wiscombe and Warren, 1980), snow albedo decreases as the grain size increases, as a smaller effective radius increases the probability that an incident photon will scatter out of the snowpack (Gardner and Sharp, 2010). Other 
important snow properties include the liquid water content, the concentration of absorbing inorganic and organic impurities in the snow, as well as their vertical distribution in the snowpack together with snow depth and albedo of the underlying ground. During melt, snow undergoes a metamorphosis process that modifies the spectral albedo (e.g., Weller, 1972). The liquid water content of snow increases, and wet snow has a lower albedo than dry snow (e.g., Blumthaler and Ambach, 1988). Also, as snow ages, with or without melting, the grain size increases and therefore albedo lowers (Wiscombe and Warren, 1980).

In turn, the key environmental factor is the solar illumination (direct and diffuse irradiance), depending on the solar zenith angle (SZA), cloud cover, and atmospheric composition (Flanner et al., 2007; Mayer and Kylling, 2005). Albedo increases as the solar elevation decreases, i.e., albedo is SZA dependent (e.g., Fig. 4 of Gardner and Sharp, 2010), because at higher angles of incidence a photon will, on average, travel a path that is closer to the surface, increasing its probability of experiencing a scattering event that will send it out of the snowpack. In addition, albedo is a scale-dependent variable, but can be measured at any selected height. The operational meteorological local albedo is defined to be measured at a standard height of 1-2 m (WMO, 2008, I. 7). Albedo measurements are influenced not only by the local snow albedo underneath the measuring radiometers, but also the combination of low-albedo and high-albedo surfaces within a larger radius. Therefore, an effective albedo is often defined to describe the net effect of the albedo, as derived by comparison with a model (Kylling et al., 2000; Bernhard et al., 2007). Finally, the ability to accurately detect the albedo of a surface depends on the measurement uncertainties and errors introduced by the measuring systems (e.g., Bernhard and Seckmeyer, 1999).

In this work, the main aim was to catch the short period of the most intensive snowmelt with the highly accurate Bentham spectrometer setup, and study snow albedo together with key parameters of seasonally melting snow beyond the Arctic Circle. The snow albedo measurements were made at Sodankylä, Finland $\left(67^{\circ} 22^{\prime} \mathrm{N}, 26^{\circ} 39^{\prime} \mathrm{E}\right)$, belonging to the northern boreal forest zone with the snow type of taiga. Our main focus was on spectral albedo, combined with broadband up-welling and down-welling radiation measurements, various ancillary environmental data, and with the modeling of diffuse and direct spectral irradiance and snow albedo. In RT calculations, the aim was to study how big effect (error) would a measured realistic change in diurnal albedo values cause on the modeled irradiance, if the observed diurnal albedo change of melting snow were ignored. In addition, RT calculations were performed to get an estimate of the edge effect (forest surrounding an open field) on the detected albedo. In albedo simulations, our aim was to study if the simulated data agreed with the measured albedo when the known big snow grain sizes of melting snow and measured Sodankylä snow impurity concentrations of elemen- tal and organic carbon were applied. For the purpose of this study, elemental carbon is used synonymously with black carbon due to their measurement technique dependence in snow impurity studies. Our aim was also to show why our snow impurity concentrations, analyzed with the thermaloptical method, were higher than expected when compared to Doherty et al. (2010).

\section{Materials and methods}

For the albedo measurements, a Bentham-spectrometer setup with two entrance optics, as well as broadband UV SL-501 radiometers and CM-14 albedometers, performed irradiance measurements during the Snow Reflectance Transition Experiment SNORTEX-2009. For investigating the effect of snow albedo on the modeled irradiance, we used the Libradtran RT model (Mayer and Kylling, 2005), with our measurement data as model input. For the albedo simulations we utilized the SNICAR on-line version (Flanner et al., 2007), with our measured snow data as model input.

\subsection{The SNORTEX experiment}

The Snow Reflectance Transition Experiment (SNORTEX, 2008-2010) aimed at acquiring in situ measurements of snow and forest properties in support of the development of modeling tools, and validating coarse resolution satellite products (Roujean et al., 2009, 2010). The goal was to integrate its results into operational chains devoted to map snow properties from the MetOp satellite within the framework of the SAF (Satellite Application Facilities) Land, Climate and Hydrology activities, supported by EUMETSAT and the national meteorological services. The SNORTEX study area was located in the Finnish Lapland beyond the Arctic Circle, and benefited from existing facilities provided by the Finnish Meteorological Institute - Arctic Research Center (FMI-ARC), based in Sodankylä $\left(67^{\circ} 22^{\prime} \mathrm{N}, 26^{\circ} 39^{\prime} \mathrm{E}, 179\right.$ m.a.s.l.). The SNORTEX sites consisted of (i) the Arctic Center at Sodankylä; with temporal daily data series of various parameters collected within SNORTEX, as well as operationally by FMI; and (ii) SNORTEX experiment sites in the Sodankylä region, representing different types of environment, e.g., open area, forested area, snow on the lake, etc.

\subsection{Albedo measurements}

For detecting snow albedo $(A)$, we measured the upwelling $Q \uparrow$ and downwelling radiation energy $Q \downarrow$ hemispherically at 2pi:

$A=\frac{Q \uparrow}{Q \downarrow}$.

Three different types of simultaneous albedo measurements at Sodankylä during SNORTEX-2009 (April period) were utilized for our study (Table 1): (i) spectral measurements 
Table 1. The hemispherical spectral and broadband albedo measurements used for the study.

\begin{tabular}{|c|c|c|c|}
\hline Instrument & Spectral range & Spectral resolution & Measurement place \\
\hline $\begin{array}{l}\text { Bentham } \\
\text { spectrometer }\end{array}$ & $290-550 \mathrm{~nm}$ & $10 \mathrm{~nm}$ spectral & $\begin{array}{l}\text { FMI Sodankylä Arctic Center, open } \\
\text { field exclusively chosen for Bentham } \\
\text { measurements within SNORTEX, size } \\
80 \mathrm{~m} \text { north-south, and } 50 \mathrm{~m} \text { east-west }\end{array}$ \\
\hline $\begin{array}{l}\text { Solar Light } \\
\text { SL-501 } \\
\text { radiometer }\end{array}$ & $280-400 \mathrm{~nm}$ & $\begin{array}{l}\text { One band with erythemal weight } \\
\text { function ( } 280-320 \mathrm{~nm} \text { most weighted) }\end{array}$ & $\begin{array}{l}\text { FMI Sodankylä Arctic Center operative } \\
\text { albedo field, size } 16 \mathrm{~m} \times 16 \mathrm{~m}\end{array}$ \\
\hline $\begin{array}{l}\text { Kipp \& } \\
\text { Zonen CM-14 } \\
\text { albedometer }\end{array}$ & $310-2800 \mathrm{~nm}$ & $\begin{array}{l}\text { One band, no weight function, the } \\
\text { relative spectral transmittance is largest } \\
(>0.5) \text { at } 400-900 \mathrm{~nm}\end{array}$ & $\begin{array}{l}\text { Three separate SNORTEX experiment } \\
\text { sites: Kommattivaara (a lightly forested } \\
\text { hill), Mantovaaranaapa (completely } \\
\text { open aapa mire) and Korppiaapa (also } \\
\text { completely open aapa mire) }\end{array}$ \\
\hline
\end{tabular}

at $290-550 \mathrm{~nm}$, on an open field at the Arctic Center (primary site of the study, Fig. 1), exclusively measured within the SNORTEX campaign during the intensive melt period of 20-24 April; (ii) continuous broadband UV albedo measurements on the operative albedo field of the FMI, Arctic Center (1 min data measured every year since 2007 , during spring time snow months, Fig. 1); and (iii) broadband albedometer measurements on three SNORTEX sites representing three vegetation types (Table 1). For the analysis of the in situ albedo data and the model data, we focused on data for solar zenith angle (SZA) $<70^{\circ}$ (06:00-14:00 UTC). The amount of radiation reaching the Earth is minimal at larger SZA, (UV Index $<1$ ), increasing uncertainties in the measurements.

\subsubsection{Bentham spectrometer}

The Bentham spectroradiometer, with a special setup of two identical entrance optics for albedo measurements, participated in the SNORTEX-2009 campaign (April period). Down-welling and up-welling spectral measurements of global irradiance (irradiance received hemispherically by a flat sensor surface) were performed at the $290-550 \mathrm{~nm}$ wavelength range. The measurement height was $2.5 \mathrm{~m}$ in order to allow the maximum distance from the spectrometer to the sensor holder (minimum loss in the optical cable length), and to be as close to the $2 \mathrm{~m}$ height recommendation by WMO as possible. These Bentham measurements were used to retrieve the spectral albedo $A(\lambda)$ of the snow surface for the spectral range $290-550 \mathrm{~nm}$ with a $10 \mathrm{~nm}$ wavelength step. The up and down measurement scans were made one after another. The measurement procedure and the parameter setup of these highly accurate measurements is not a trivial task. Here, a 6 min time step was used for clear sky conditions, and a 2 min step was elaborated for variable cloudiness, to optimize the measurement setup and minimize the changes in SZA and cloudiness during the measurements.
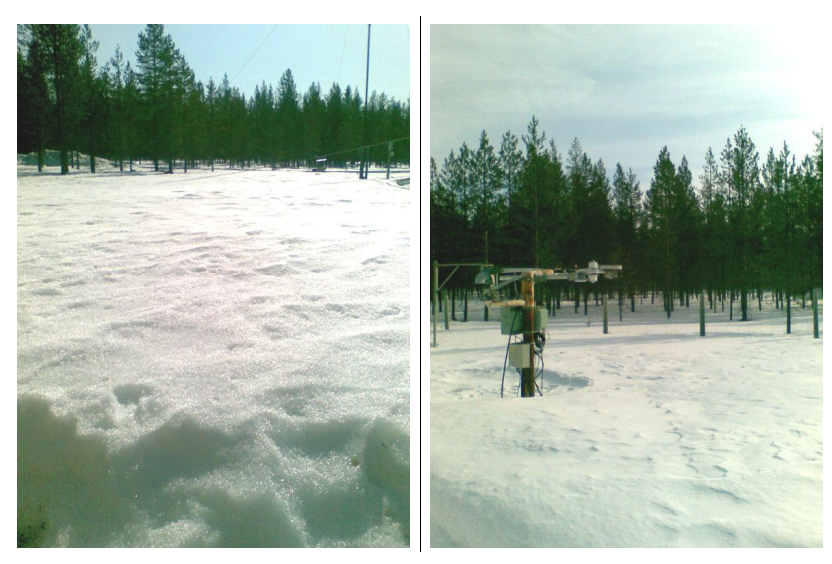

Fig. 1. The Bentham spectral albedo field (left), and the broadband SL-501 UV albedo field (right), at the Sodankylä Arctic Research Center.

The Bentham albedo field had been protected for this particular purpose since autumn, to provide undisturbed snow. The mast and holder with the proper leveling possibility had been tailored and mounted in autumn, and the instrument was transported from FMI Helsinki for the purpose. The intensive melt period started 21 April, and the Bentham was operated from 20 to 25 April. At the end of the measurement period, the snow was practically melted from this particular field. For 21 and 23 April, the sky conditions were with variable cloudiness, resulting changes in the radiation field. 22 April was a cloudless day, and 24 April an overcast day with mainly diffuse sky conditions (Fig. 2).

The size of the open Bentham albedo field was $80 \mathrm{~m}$ northsouth, and $50 \mathrm{~m}$ east-west, situated close to the Sodankylä ozone sounding station. The surface underneath the two Bentham sensors (at the height of $2.5 \mathrm{~m}$ from the ground) was covered with snow in a radius of more than $10 \mathrm{~m}$ on the south, west and east direction, and up to $3 \mathrm{~m}$ in the north direction. 


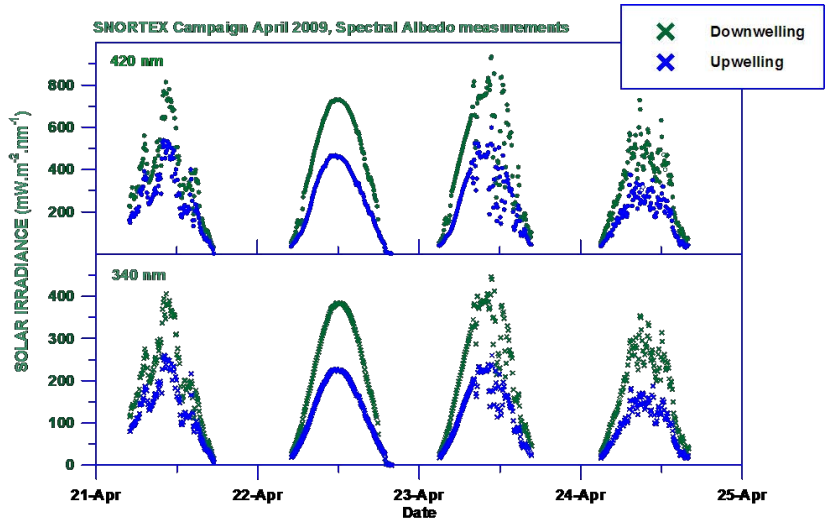

Fig. 2. Global downwelling and upwelling irradiance for $340 \mathrm{~nm}$ and $440 \mathrm{~nm}$ during the campaign.

The field of view of the sensors was mostly free. Direct Sun irradiance was blocked by trees from 03:00 to 05:00 UTC, and after 17:00 UTC. In addition, shadows of the trees were covering all or part of the snow surface underneath the instruments in the morning till 06:10 UTC, and after 15:30 UTC.

The Bentham spectroradiometer system consists of a commercially available Bentham DM-150 double monochromator with a focal length of $150 \mathrm{~mm}$, and with gratings of 2400 lines $\mathrm{mm}^{-1}$. The entrance and exit slit widths were chosen to yield a nearly triangular slit function, with a full width at half maximum (FWHM) resolution of $0.74 \mathrm{~nm}$. The solar irradiance is sampled through a specially designed entrance optics (CMS Schreder, Model UV-J1002), connected to the port of the spectroradiometer through a quartz fiber. The fiber optic splits and leads to two identical entrance optics receivers (diffusers) that can be distinguished through an internal switch. The angular response of the two diffusers is better than $2 \%$ for incident angles less than 70 degrees. As the instrument is designed for outdoor solar measurements, the whole spectroradiometer system, including the data-acquisition electronics, is contained in a temperaturecontrolled box that is stabilized to a predetermined temperature with a precision of $0.5 \mathrm{~K}$. Absolute irradiance scale calibration is performed using measurements of calibrated $1000 \mathrm{~W}$ quartz halogen lamps. To measure at locations far from its laboratory, a portable irradiance scale was devised. It is composed of a portable lamp enclosure (calibrator), a set of 100 and $250 \mathrm{~W}$ tungsten halogen lamps, and a feedback system. For this particular campaign, the two entrance optics were used for measurements of the down-welling and the up-welling global solar irradiance. The calibration of the instrument was performed at the beginning and at the end of the campaign, showing deviations of less than $\pm 1 \%$ for the entire spectral range based on measurements of the three lamps used for the calibration procedure.

\subsubsection{Broadband UV albedo}

Broadband UV albedo data were provided by continuous bihemispherical data of two radiometers (Model SL501, Solar Light Co.) which were located $20 \mathrm{~m}$ away from the site of the spectroradiometric measurements. The UV albedo is detected above the FMI Sodankylä Arctic Center operational albedo field (size $16 \mathrm{~m} \times 16 \mathrm{~m}$, low metal fences protecting the operational field). These measurements were started in 2007 as part of the International Polar Year IPY (2007-2008) ORACLE-O3 cluster project (Ozone layer and UV radiation in a changing climate evaluated during IPY, http://www. awi-potsdam.de/atmo/ORACLE-O3, Meinander et al., 2008, 2009). Two well maintained and calibrated SL501 sensors with similar spectral and cosine responses were used (Fig. 1 of Meinander et al., 2008); one facing upwards, and the other downwards, at a height of $2 \mathrm{~m}$. The data are recorded in $1 \mathrm{~min}$ intervals and stored in the FMI climate database. The SL501 resembles the action spectrum from erythema (Seckmeyer et al., 2005), which also has a contribution from the UVA. The SL501 measured dose of the radiant energy $Q_{\text {ery }}$ is calculated as the temporal and spectral integral of the convolution of the global solar spectral irradiance and the erythemal response (Grainger et al., 1993), measured hemispherically at 2 pi. To gain the erythemally weighted broadband albedo $A_{\text {ery }}$, the ratio of the hemispherically measured up-welling $(\uparrow)$ to down-welling $(\downarrow)$ UV solar radiation is then calculated:

$A_{\text {ery }}=\frac{Q_{\text {ery }} \uparrow}{Q_{\text {ery }} \downarrow}$

where $Q_{\text {ery }}$ is the bi-hemispherically measured temporal $(T)$ and spectral $(\lambda)$ integral of the convolution of the solar radiance $(E)$ and the erythemal response function $(\varepsilon)$ is

$Q_{\text {ery }}=\int_{T 1}^{T 2} \int_{\lambda 1}^{\lambda 2} E(\lambda, T) \varepsilon(\lambda) \mathrm{d} \lambda \mathrm{d} T$.

As the hemispherical global solar spectral irradiance is used for the calculation of the dose, the measured downwelling irradiance includes both the direct and diffuse components, and the upwelling part consists of the hemispherically reflected global spectral diffuse radiance, similarly to any nonweighted sensor used for an albedo measurement.

\subsubsection{Broadband visible albedo}

The broadband albedo observations from three days during SNORTEX-2009 were measured with a Kipp \& Zonen CM14 albedometer (www.kippzonen.com) at one non-weighted broadband from 310 to $2800 \mathrm{~nm}$, whose accuracy may be estimated at $5-10 \%$ relative. The general technical data of CM-11 pyranometer applies to the CM-14 albedometer, and the relative spectral transmittance is largest $(>0.5)$ at 400 $900 \mathrm{~nm}$. 
The observations were made at SNORTEX sites of (a) Kommattivaara (a lightly forested hill) during 20 April, (b) Mantovaaranaapa (a completely open aapa mire) during 22 April, and (c) Korppiaapa (also a completely open aapa mire) during 23 April. The CM-14 instrument was carefully leveled on a tripod and operated without breaks during the field day. During postprocessing, the data were corrected for the shadowing effect of the tripod legs and imperfections in cosine response at high solar zenith angle conditions after Michalsky et al. (1995).

All three days were effectively clear-sky, with no significant cloud disturbances on the observed irradiance. There were no obstructions in the path of the incoming solar radiation during the measurements of 22 April or 23 April 2009. Some tree shadows disturbed the measurements on 20 April. The instrument was mounted at a height of $1.5 \mathrm{~m}$, implying an observed area with a radius of $15 \mathrm{~m}$. Thus, the observed albedo may be seen as representative of the areal mean of the mire (or open woodland in the case of 20 April).

\subsection{Snow properties}

\subsubsection{Snow depth and snow liquid water content}

Snow depth was measured manually with a measurement stick in the Bentham spectral albedo field. For the measurements of snow liquid content in the same field, we used the commercially available Snow Fork by Toikka Oy (www.toikkaoy.com). The sensor is a steel fork that is used as a microwave resonator. The Snow Fork measures the electrical parameters: resonant frequency, attenuation, and $3 \mathrm{~dB}$ bandwidth. From these measurement results, the liquid water content is calculated as described in detail in Sihvola and Tiuri (1986), and Toikka (1992). In addition to the actual snow liquid water content, the snow impurities and grain sizes, hardness and density, etc., may affect the measurement results.

\subsubsection{Snow grain size, temperature and snowball-test}

The measurements on snow grain size, snow temperature and the snowball test were made at the Bentham spectral albedo field, on the north side of the field where the Bentham was measuring towards the south, and thus with snow facing similar radiation conditions as those under the Bentham sensor.

The temporal changes in the snow grain sizes and shapes, according to Fierz et al. (2009), were both estimated visually with a mm-grid, and the snow grains on the grid were also macro-photographed to allow image analysis afterwards. An example of such a photo is in Meinander et al. (2008, Fig. 4).

The snow temperature was measured with a digital Printel thermometer (www.printel.fi). The thermometer was calibrated using isopropanol measured with a Fluke accuracy thermometer in the measured temperatures from $-20.72^{\circ} \mathrm{C}$ to $+1.218^{\circ} \mathrm{C}$ at 99 different temperatures. Empirical cali- bration was calculated and the measured snow temperatures were corrected using this calibration.

A simple "snowball-test" was also made periodically in the Bentham albedo field. The test is in regular use in all Sodankylä snow research. This practical test tells if the properties of snow are such that one succeeds in making a snowball out of the snow on the ground. Snowballs can only be made when snow properties are suitable for making them; i.e., snow contains water but is not yet too wet. With the test, for instance the start of snowmelt can be easily detected, as corresponding snow property information would be hard to determine otherwise.

\subsubsection{Snow elemental carbon and organic carbon contents}

At the Sodankylä Arctic Center, snow surface (first $2 \mathrm{~cm}$ of snow) samples have been collected from the same location for impurity analysis since 2009 on a weekly basis during snow time, the location protected with reindeer fences. Sampling and analysis follow the same general methodology developed by Forsström et al. (2009) and Aamaas et al. (2011), in which snow samples are melted in a microwave oven, then filtered through sterilized micro-quartz filters $(55 \mathrm{~mm}$ diameter) using a hand pump attached to the filtering system to create a vacuum during filtering. The volume of meltwater is needed for concentration conversions. Dried filters are analyzed with a Thermal/Optical Carbon Aerosol Analyzer (OC/EC) (Sunset Laboratory Inc., Forest Grove, USA) for their elemental carbon (EC) and organic (OC) concentration, following the NIOSH 5040 protocol developed by Birch (2003). The thermal-optical method was created by Birch and Cary (1996), where a detailed description of the method is presented.

One of these routine snow impurity samplings took place during the intensive melt days (24 April), one right before (17 April) and one after (30 April). The data from 2009 are used in our study related to the measured albedo. The data from 2009-2011 are used for the transport analysis to study the origin of the $\mathrm{BC}$ in snow.

\subsection{Other ancillary data}

The Sodankylä automatic weather station (AWS) measures the state of the atmosphere at a height of $2 \mathrm{~m}$ once a minute. From these data, information on, e.g., the onset of precipitation, snow depth and cloud cover, can be gained. The Sodankylä Arctic Center measurement program includes a large variety of environmental parameters; here use was made of, e.g., the measured aerosol parameters and total ozone as input values for the RT calculations (Sect. 2.5).

\subsection{RT and albedo model calculations}

We used the Libradtran RT model (Mayer and Kylling, 2005) to calculate the up-welling and down-welling diffuse and 
direct spectral irradiances during a cloudless day (22 April). The measured spectral albedo (Bentham spectroradiometer data), total ozone (Sodankylä ozone sounding; Brewer spectrophotometer data), and aerosol properties measured with a Precision Filter Radiometer/SunPhotometer (http://litdb.fmi. fi/) were used as main inputs for the RT calculations. Our hypothesis was the following: the measured diurnal albedo change is big enough to have an impact on the solar irradiance at the surface level. The albedo values used in the RT model were the ones measured with the spectroradiometer. Solar irradiances were calculated from the RT model using the morning albedo value and were compared with irradiances that were calculated using the albedo as measured at various times during the day. A difference in irradiance in [\%] between the morning and afternoon would indicate changes in radiative forcing caused by changes in albedo due to melting snow. Only relative changes were considered when comparing measurements with the model to eliminate the effect of absolute calibration scale uncertainties of the measurement data. The absolute calibration scale should not affect the albedo measured by the Bentham spectroradiometer, as the same monochromator/light directing system is used for both the upward and downward sensors.

The edge effect on albedo (i.e., the effect of forest surrounding the open albedo field) was studied on the assumption of a Lambertian surface (Meinander and Räisänen, 2010) (see also Sect. 4.7).

We also used the Snow, Ice, and Aerosol Radiation (SNICAR) on-line version (Flanner et al., 2007) to gain simulated data on snow albedo to compare with in situ albedo data. The measured parameter values of snow depth, snow grain size and elemental carbon (BC) content were used as input values to simulate a clear sky case (day 22 April) and a diffuse sky case (24 April). In SNICAR-online, there are two types of black carbon input parameters: (1) uncoated (mimicking hydrophobic particles), with properties tuned to achieve a mass absorption cross-section of $7.5 \mathrm{~m}^{2} \mathrm{~g}^{-1}$ at $550 \mathrm{~nm}$ (Bond and Bergstrom, 2006); and (2) sulfate-coated black carbon (mimicking hydrophilic black carbon), which is composed of a weakly-absorbing shell (sulfate) surrounding black carbon, resulting in an absorption enhancement (per unit mass of black carbon) of about 1.5 (Bond et al., 2006). Most of the BC in the snow at Sodankylä can be assumed to originate from longer transport, and therefore the $\mathrm{BC}$ in snow can be assumed to become hydrophilic. Yet, with the current snow analysis data we cannot determine that all BC would be hydrophilic. Therefore, in our simulated data, we used both these options separately to compare their effect on albedo. For melting seasonal snow in northern Finland, the averaged snow density values of $329 \mathrm{~kg} \mathrm{~m}^{-3}$ for forest, and $349 \mathrm{~kg} \mathrm{~m}^{-3}$ for open sites, have been reported (Kuusisto, 1984). From these we used the value reported for northern Finland.

\subsection{Source identification for snow impurities}

The impurities at melting snow surface can be either brought there together with the snowfall or result from dry deposition to the snow surface. To identify the sources of snow pollution at Sodankylä we have used the mixing ratio of elemental carbon in surface snow samples collected weekly in Sodankylä during 2009-2011. According to simple models of wet deposition, the concentration of a pollutant in precipitation is proportional to the column concentration in the air below a cloud layer. Thus concentrations in samples of fresh snow can be used to quantify in-air concentrations during preceeding snowfall.

A qualitative analysis of the origins of pollution in the air can be done with simple backward trajectories. For quantitative and comparatively accurate assessment in case of limited observational information, the so-called "footprint" computations can be used (e.g., Prank et al., 2010). This approach is based on solving the adjoint dispersion equation for, e.g., an isolated episode registered by a single measurement device. The resulting fields describe the sensitivity distribution of that particular measurement to a source location, e.g., the observed values can be affected only by the emission fluxes from the area where the sensitivity is nonzero.

The modeling was performed with SILAM (System for Integrated modeLing of Atmospheric coMposition) version v5_2. The system has Eulerian non-diffusive advection scheme of Galperin (2000) and the adaptive vertical diffusion algorithm of Sofiev (2002). For a more detailed description we refer to Sofiev et al. (2008) and http://silam.fmi.fi. The verification of the model has been performed within the scope of EU-GEMS project (http://www.ecmwf.int/gems) and is continued on a routine basis within the EU-MACC (http://www.gmes-atmosphere.eu).

The meteorological fields from short-term operational forecasts of the European Centre for Medium-range Weather forecasts (ECMWF) were used as a driver for SILAM. The adjoint simulations were performed with resolution $0.5 \times$ 0.25 degree on a domain $10-60^{\circ}$ E. $55-75^{\circ} \mathrm{N}$ (shown in Fig. 9) with 8 vertical layers of thickness from $30 \mathrm{~m}$ at surface to $2000 \mathrm{~m}$ within a height range from surface to $6 \mathrm{~km}$. The footprints were taken for the layer 150-300 m, which we expect to correspond to the height of industrial emissions due to combustion.

The observational function of atmospheric concentrations corresponding to measured in-snow concentrations was taken to be uniform with height from the surface to the bottom of a cloud and weighted by snowfall intensity in time, so total sensitivity is unity. The footprints were calculated for each sample separately. To minimize the effect of dry deposition and to ensure the consistency between observed and modeled snowfalls, only the cases were selected when snowfall was reported by both the weather station at Sodankylä and the meteorological driver, reporting more than $1 \mathrm{~mm}$ snowfall within $24 \mathrm{~h}$ before the sample collection and 
the amount of the precipitation agreeing within a factor of 2 between them. The volumetric content of black carbon was used as a tracer of anthropogenic pollution. With above criteria out of 70 snow samples we selected 10 "clean" $(<20 \mathrm{ppb}$ of BC) and 12 "dirty" (>30 ppb of BC) samples and calculated the average footprint for both classes. Since the size of air-borne black carbon is unknown, the footprints were calculated for passive gas with no deposition, for $1.5 \mu \mathrm{m}$ (fine) particles and for $20 \mu \mathrm{m}$ (coarse) particles.

\section{Results}

\subsection{Spectral albedo}

The measured Bentham albedo values were $0.5-0.7$ for the ultraviolet and visible range, both under clear sky and variable cloudiness (Figs. 2 and 3). During the four days of intensive melt, the spectral Bentham albedo at $330 \mathrm{~nm}$ decreased from $\sim 0.65$ (the morning of the first day) to 0.45 (the afternoon of the fourth day). At $450 \mathrm{~nm}$, the decrease was from 0.72 to 0.53 , accordingly. During each day, the albedo decreased on average by approx. $10 \%$. The albedo was higher in the morning than in the afternoon, i.e., the albedo was asymmetric to SZA. Also, in the mornings, the albedo signal was slightly higher than it had been the previous evening.

To understand the spectral behavior of albedo under our circumstances (i.e., intensively melting snow with big effective snow grains), we studied the measured albedo as a function of wavelength (Fig. 4). Irrespective of any possible albedo SZA symmetry or asymmetry, the snow albedo at any given time increased as a function of wavelength. During the clear sky day of 22 April, an average difference of $\sim 8 \%$ in the calculated albedo was found when comparing UVB (at $320 \mathrm{~nm}$ ) and visible (at $550 \mathrm{~nm}$ ) wavelengths. Deviations up to $5 \%$ from this spectral behavior could be seen during the day. We then calculated the mean values for UVB (at $310 \mathrm{~nm}$ ), UV-A (at 330-360 nm) and visible (at 450$550 \mathrm{~nm}$ ). The regression of snow albedo $A$ for UV-A, applying the shortest measured wavelengths of $A(\mathrm{UV}-\mathrm{B})$, were in our Bentham spectra:

$A(\mathrm{UV}-\mathrm{A})=1.0049 A(\mathrm{UV}-\mathrm{B})+0.0054,\left(R^{2}=0.9744\right)$,

$A(\mathrm{VIS})=1.1602 A(\mathrm{UV}-\mathrm{B})-0.0213,\left(R^{2}=0.6012\right)$,

for SZA $<70.0$ degrees, under clear sky conditions on melting snow measured at $2.5 \mathrm{~m}$ height.

\subsection{Broadband UV and VIS albedo}

The broadband erythemal SL-501 UV albedo, representing the FMI operational albedo field, decreased both within a day (from morning till afternoon), and as a function of time (days) (Fig. 5). For example, on 22 April, from 06:00 UTC to 12:00 UTC, the decline in albedo was $10 \%$. The UV albedo

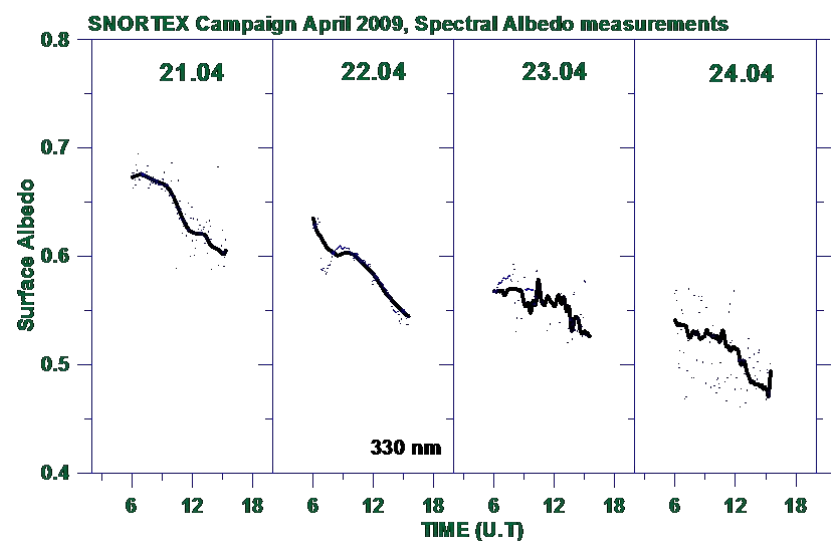

Fig. 3. Snow albedo at $330 \mathrm{~nm}$, during 21-24 April, 2009. Blue dots represent 6 min period measurements, and black line time interpolated $1 \mathrm{~min}$ ratios.

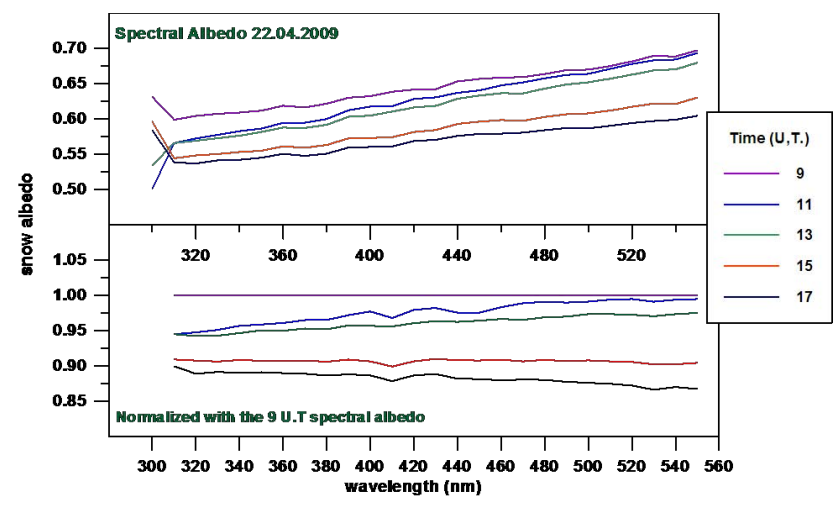

Fig. 4. The snow albedo increased as a function of wavelength. (Upper panel) Spectral snow albedo for 22 April for different periods during the day. (Lower panel) Ratio of each of the above spectral measurements to the 09:00 UTC measurement.

values (17-30 April) ranged from 0.51 to 0.38 in the morning, and from 0.48 to 0.37 in the afternoon.

The broadband CM14 albedo revealed values of $\sim 0.6-$ 0.75 (Fig. 6). The data of three various SNORTEX sites showed that (a) the broadband albedos were significantly lower than for even aged midwinter snow (measured during other SNORTEX experiments), (b) observed albedos decrease during a single field day owing to snow metamorphism and surface melt, and (c) the level of the broadband albedos fell consistently during the four-day period as the melt season progressed. The very large albedo decrease observed on 20 April arises from a combination of snowmelt and metamorphism effects and lengthening tree trunk shadows, which both decrease the observable reflected radiation flux. The different albedo decrease rates observed on 22 and 23 April are most likely a result of several factors. The snow characteristics at the observed site were somewhat different, and also the air temperature on the night between 22-23 April was below freezing only for a few hours (not shown), 


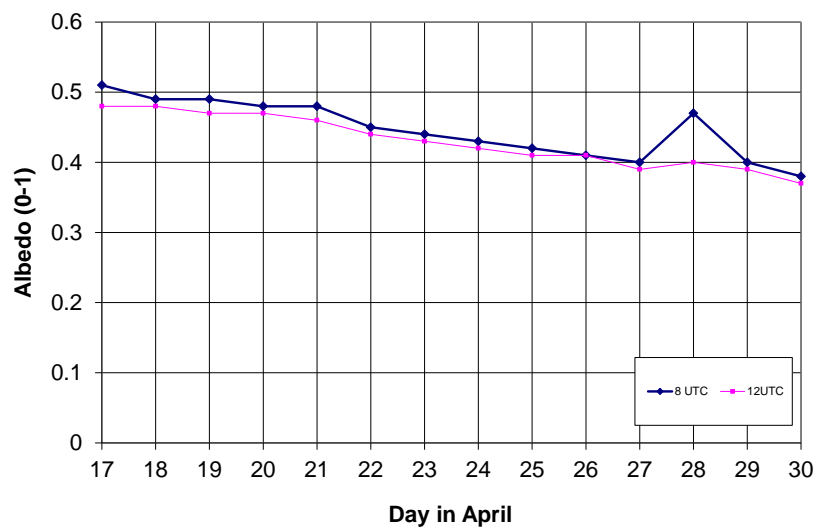

Fig. 5. The broadband erythemal UV albedo of snow from 17 April to 30 April 2009, measured with SL-501 radiometers, at the operational albedo field of the Sodankylä Arctic Research Center. The albedo declined slightly during each day: blue line for 08:00 UTC, purple line for 12:00 UTC.

implying that the snow surface did not have the chance to refreeze properly, leading to a lower albedo already at the start of the measurement day of 23 April.

\subsection{Snow properties and AWS results}

Between 20-24 April, an intensive snowmelt process took place at the open field of our Bentham spectrometer albedo (Table 2). On 20 April, there was a new snow layer on the snow surface. The snowball tests revealed that the snow was not yet melted to the extent that snowballs could be made. This was the case also the next day 21 April at 13:50 UTC. Later that day, the conditions changed. At 16:38 UTC, the snowball test was successful. After almost $2 \mathrm{~h}$ later, the snowball test failed again. The new snow layer could still be seen on the snow surface, although it was now wet. On 22 April, the new snow layer could no longer be separated at the surface. The snowball test was successful during the day. The melt process was under way. The snow depth (data not shown) was manually measured to change from $30 \mathrm{~cm}$ to totally melted in some places. The automatically measured snow height at the Sodankylä AWS measurement place declined from $48 \mathrm{~cm}$ to $38 \mathrm{~cm}$.

The data on snow liquid water content (Fig. 7), as a function of time and snow depth, at the same field as the Bentham measurements, showed that when the first measurement was taken (at about 07:00), the highest water content was at the deepest depth $(24 \mathrm{~cm})$. The changes in the water content were such that the water content started to increase in the surface layer, whereafter the surface values dropped. At the same time the concentrations in the deeper layers were first lower and increased later.

The snow temperature of the same area showed both a vertical and temporal increase during the study days (Fig. 6 of Meinander et al., 2010), and the snow surface observations

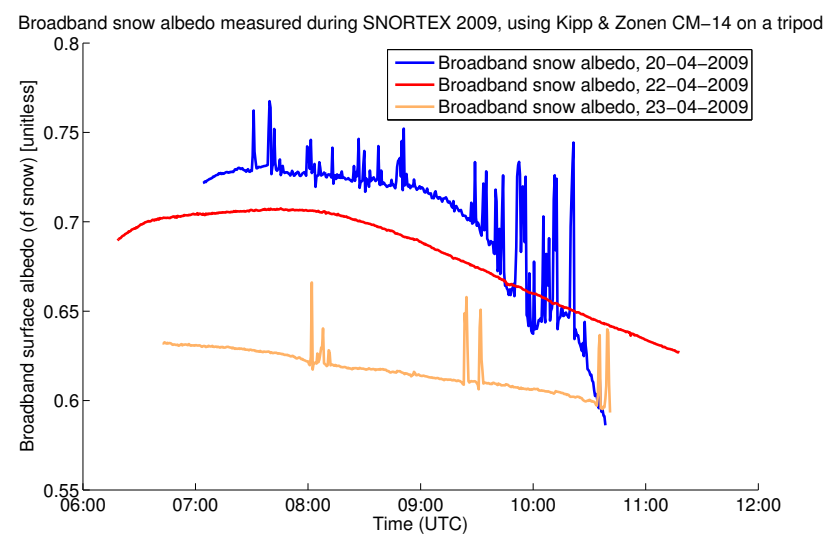

Fig. 6. The broadband VIS albedo of snow measured with CM4 at SNORTEX sites of (a) Kommattivaara (a lightly forested hill) during 20 April, (b) Mantovaaranaapa (a completely open aapa mire) during 22 April, and (c) Korppiaapa (also a completely open aapa mire) during 23 April.

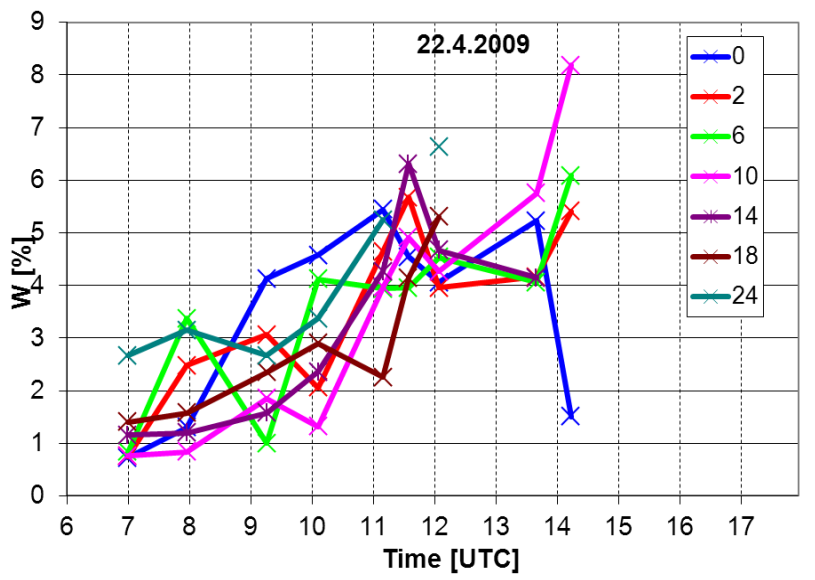

Fig. 7. The snow liquid water content on 22 April as a function of time and snow depth $(0,2,6,10,14,18,24 \mathrm{~cm})$. The data shows that the water content first increased in the surface layer. Later, the water content was higher at deeper layers.

indicated an intensive melt on 22 April, with snow grain sizes changing from $0.25 \mathrm{~mm}$ up to 3 millimeters (Table 2). Also, on the basis of image analysis, the snow surface grain shapes changed from 21 April to 22 April: there were first surface hoar crystals (SHsu), then rounding surface hoar (SHxr) and then later melt forms, rounded polycrystals (MFpc) (Table 2).

The AWS data showed that at 06:00 UTC the air temperatures were $<0{ }^{\circ} \mathrm{C}$ during 20-21 April, and $>0{ }^{\circ} \mathrm{C}$ on 22-24 April. During those days, the maximum air temperatures varied from -2.5 to $5.4^{\circ} \mathrm{C}$, and at 18:00 UTC, the air temperatures were always $>0{ }^{\circ} \mathrm{C}$, with maximum temperatures from 0.5 to $9.5^{\circ} \mathrm{C}$. 
Table 2. Snow conditions during the time [UTC] of the spectral albedo measurements. The snow grain shapes are according to Fierz et al. (2009).

\begin{tabular}{|c|c|}
\hline Day/Time & Snow Surface \\
\hline \multicolumn{2}{|l|}{20 April } \\
\hline $17: 46$ & Snowball test: negative \\
\hline \multicolumn{2}{|l|}{21 April } \\
\hline 09:15 & $\begin{array}{l}\text { Snow surface layer } 0.5 \mathrm{~cm} \text { with surface hoar crystals (SHsu), under that a layer } \\
\text { with melt forms, rounded polycrystals }(\mathrm{MFpc})\end{array}$ \\
\hline $13: 50$ & Snowball test: negative, grain size $0.25 \mathrm{~mm}$, new snow layer exists, icy snow \\
\hline $14: 45$ & $\begin{array}{l}\text { Snow surface layer } 0.5 \mathrm{~cm} \text { with rounding surface hoar (SHxr), under that a layer } \\
\text { with melt forms, melt freeze crust (MFcr) }\end{array}$ \\
\hline $16: 38$ & $\begin{array}{l}\text { Snowball test: positive, } 1 \mathrm{~mm} \text { grains melted together, sunny cloudless calm } \\
\text { weather; melting snow, new snow layer exists }\end{array}$ \\
\hline $17: 30$ & Wet new snow layer exists, surface layer of $0.5 \mathrm{~cm}$ \\
\hline $18: 19$ & Snowball test: negative \\
\hline \multicolumn{2}{|l|}{22 April } \\
\hline 09:35 & $\begin{array}{l}\text { Surface layer of } 0.5 \mathrm{~cm} \text { with melt forms, rounded polycrystals (MFpc), under } \\
\text { that a layer with melt forms, melt freeze crust (MFcr) }\end{array}$ \\
\hline $12: 35$ & $\begin{array}{l}\text { No new snow layer, icy snow, } 0.5 \mathrm{~cm} \text { surface layer with grain minimum size } \\
0.25 \mathrm{~mm} \text {, maximum size } 1 \mathrm{~mm} \text {, all stick together; the rest of the snow is } 1.5- \\
5 \mathrm{~mm} \text { grains and sticks together }\end{array}$ \\
\hline 13:00 & $1 \mathrm{~mm}$ grains, sunny weather, clear sky \\
\hline $13: 58$ & $2 \mathrm{~mm}$ grains on the surface \\
\hline $15: 17$ & Snowball test: positive, $2-3 \mathrm{~mm}$ grains on the surface, wet snow \\
\hline 16:08 & $3 \mathrm{~mm}$ grains \\
\hline $17: 12$ & Snowball test: positive, $3 \mathrm{~mm}$ grains, wet snow \\
\hline $20: 17$ & Wet snow, $3 \mathrm{~mm}$ grains, fluffy surface \\
\hline
\end{tabular}

\subsection{RT modeling}

For the clear sky day 22 April, for SZA 55-70, the spectroradiometer measured albedo minimum was $A_{\min }=0.54$, the maximum $A_{\max }=0.65$ at $330 \mathrm{~nm}$. The measured spectral albedo $A(\lambda)$ was dependent on the time $t$. These were used as input parameter values for the RT calculations. The irradiance spectra were modeled from 06:00 UTC to 14:00 UTC to produce the spectra $\mathrm{S} 1\left(t, A_{\min }(L)\right), \mathrm{S} 2\left(t, A_{\max }(L)\right)$, and $\mathrm{S} 3(t, A(\lambda))$, where $\mathrm{S} 1, \mathrm{~S} 2$ and $\mathrm{S} 3$ are the various types of modeled spectra (from 1 to 3 ), $t$ is time, $A$ is albedo, $A_{\min }=$ $0.54, A_{\max }=0.65, L$ is the Lambertian assumed reflectance, and $A(\lambda, t)$ is the actual measured spectral albedo. Instead of the Lambertian RT model assumption of an isotropic surface (independent of the direction), the actual measured spectral albedo $A(\lambda, t)$ is influenced by the forward-scattering nature of snow. A Lambertian albedo can still depend on wavelength. The values of the other measured input parameters for both types of RT calculations were as follows: Ångström parameters $\alpha=1.253$ and $\beta=0.038$ (for the calculation of aerosol optical thickness $\tau a=\beta \lambda^{-\alpha}$ ), and 347 DU for ozone. The maximum difference was observed when $A_{\max }$ was used for the model calculations, as in reality the albedo was decreasing as a function of time. For the same reason, the measured irradiance was expected to be closest to the case of $A_{\min }$, as confirmed by our modeling results (data not shown). The differences were $2.5-4.5 \%$ for wavelengths from 320 to 400 for this one day showing the $10 \%$ change in the albedo (Fig. 8). The difference was calculated to be up to $9 \%$ when using the results for the 4 days of the melting snow period.

\subsection{Snow impurities}

Sodankylä results on the impurities in snow, in parts per billion by mass (ppb), showed that during the intensive snowmelt period (24 April), EC was $87 \mathrm{ppb}$, and OC $2894 \mathrm{ppb}$ (Table 3). Prior to this, both EC (16 ppb) and OC (988 ppb) concentrations were much lower. At the very end of the melt period (30 April), EC remained at the same level as during the melt ( $86 \mathrm{ppb}$ ), but the OC was as high as $7172 \mathrm{ppb}$. The Sodankylä snow impurity results from years 2009-2011 suggest some increase of OC toward the late spring (many days with $>2000 \mathrm{ppb}$ in April). The EC results showed, in addition to the increase in EC toward spring, some variability from day to day, with concentrations between 9$106 \mathrm{ppb}$. 
Table 3. Results of EC and OC [ppb] in the snow samples of the Sodankylä Arctic Research Center, since the beginning of 2009 until the snowmelt in spring 2011.

\begin{tabular}{|c|c|c|c|c|}
\hline \multirow[b]{2}{*}{ Date } & \multicolumn{4}{|c|}{ Concentration } \\
\hline & $\begin{array}{c}\mu g \mathrm{~L}^{-1} \\
\text { Organic C }\end{array}$ & $\begin{array}{c}\mu \mathrm{gL}^{-1} \\
\mathrm{OC} \pm\end{array}$ & $\begin{array}{r}\mu \mathrm{gL}^{-1} \\
\text { Elemental C }\end{array}$ & $\begin{array}{r}\mu \mathrm{g} \mathrm{L}^{-1} \\
\mathrm{EC} \pm\end{array}$ \\
\hline 21.1.2009 & 1751.1 & 90.3 & 31.6 & 4.3 \\
\hline 30.1.2009 & 1051.2 & 55.5 & 38.2 & 4.7 \\
\hline 6.2 .2009 & 974.5 & 51.4 & 17.3 & 3.6 \\
\hline 20.2.2009 & 492.1 & 27.1 & 23.6 & 3.6 \\
\hline 27.2.2009 & 816.6 & 43.6 & 19.1 & 3.8 \\
\hline 6.3 .2009 & 575.1 & 31.4 & 22.7 & 3.9 \\
\hline 13.3.2009 & 925.6 & 49.0 & 20.6 & 3.8 \\
\hline 13.3.2009 & 482.7 & 26.6 & 38.5 & 4.4 \\
\hline 20.3.2009 & 1844.9 & 95.9 & 18.8 & 4.5 \\
\hline 27.3.2009 & 1518.5 & 78.8 & 41.5 & 5.3 \\
\hline 3.4.2009 & 2870.5 & 146.1 & 48.1 & 5.0 \\
\hline 10.4.2009 & 3342.0 & 169.6 & 106.3 & 7.8 \\
\hline 17.4.2009 & 988.0 & 51.8 & 15.7 & 3.2 \\
\hline 24.4.2009 & 2894.0 & 147.3 & 87.1 & 6.9 \\
\hline 30.4.2009 & 7171.9 & 361.3 & 85.7 & 6.9 \\
\hline 4.12 .2009 & 236.4 & 14.3 & 16.9 & 3.4 \\
\hline 11.12.2009 & 203.6 & 12.8 & 46.3 & 5.0 \\
\hline 18.12.2009 & 288.3 & 16.9 & 55.0 & 5.3 \\
\hline 25.12.2009 & 850.2 & 45.0 & 36.9 & 4.3 \\
\hline 1.1 .2010 & 533.6 & 29.2 & 52.8 & 5.2 \\
\hline 8.1 .2010 & 161.1 & 10.5 & 20.4 & 3.6 \\
\hline 15.1 .2010 & 467.6 & 25.7 & 22.6 & 3.5 \\
\hline 22.1.2010 & 2263.4 & 115.7 & 84.2 & 6.7 \\
\hline 29.1.2010 & 2057.5 & 105.3 & 54.7 & 5.2 \\
\hline 5.2 .2010 & 415.3 & 23.4 & 16.8 & 3.5 \\
\hline 12.2 .2010 & 249.9 & 15.0 & 16.1 & 3.3 \\
\hline 19.2.2010 & 216.9 & 13.4 & 15.7 & 3.3 \\
\hline 26.2.2010 & 274.2 & 16.2 & 21.9 & 3.6 \\
\hline 5.3 .2010 & 3337.9 & 169.3 & 32.6 & 4.1 \\
\hline 12.3.2010 & 1502.6 & 77.9 & 15.1 & 3.5 \\
\hline 19.3.2010 & 787.0 & 41.8 & 24.1 & 3.8 \\
\hline 26.3 .2010 & 167.3 & 10.9 & 9.4 & 3.1 \\
\hline 2.4.2010 & 242.5 & 14.6 & 23.2 & 3.6 \\
\hline 9.4 .2010 & 1860.1 & 95.7 & 32.3 & 4.3 \\
\hline 16.4.2010 & 1784.6 & 91.8 & 26.7 & 3.4 \\
\hline 23.4 .2010 & 4312.0 & 218.2 & 59.3 & 5.5 \\
\hline 30.4 .2010 & 4442.1 & 224.6 & 52.9 & 5.1 \\
\hline 7.5.2010 & 5367.5 & 271.0 & 56.8 & 5.5 \\
\hline 14.5.2010 & 15324.4 & 768.7 & 59.7 & 5.5 \\
\hline 29.10 .2010 & 380.5 & 21.5 & 14.6 & 3.2 \\
\hline 5.11 .2010 & 378.7 & 21.4 & 37.3 & 4.4 \\
\hline 12.11 .2010 & 522.5 & 28.6 & 34.4 & 4.3 \\
\hline 3.12 .2010 & 428.1 & 23.9 & 36.6 & 4.3 \\
\hline 19.11.2010 & 585.1 & 31.7 & 29.8 & 4.1 \\
\hline 26.11.2010 & 520.4 & 28.5 & 35.0 & 4.3 \\
\hline 10.12 .2010 & 130.3 & 9.0 & 14.4 & 3.3 \\
\hline 17.12.2010 & 683.1 & 36.6 & 12.4 & 3.2 \\
\hline 24.12.2010 & 425.0 & 23.6 & 15.5 & 3.1 \\
\hline 31.12 .2010 & 121.1 & 8.5 & 20.5 & 3.5 \\
\hline 7.1.2011 & 226.2 & 13.7 & 16.7 & 3.3 \\
\hline
\end{tabular}

Table 3. Continued.

\begin{tabular}{lrrrr}
\hline & \multicolumn{4}{c}{ Concentration } \\
\cline { 2 - 5 } Date & $\mu \mathrm{g} \mathrm{L}^{-1}$ & $\mu \mathrm{g} \mathrm{L}^{-1}$ & $\mu \mathrm{g} \mathrm{L}^{-1}$ & $\mu \mathrm{g} \mathrm{L}^{-1}$ \\
& Organic C & $\mathrm{OC} \pm$ & Elemental C & $\mathrm{EC} \pm$ \\
\hline 14.1 .2011 & 133.4 & 9.1 & 19.1 & 3.4 \\
21.1 .2011 & 89.0 & 7.0 & 24.7 & 3.9 \\
28.1 .2011 & 556.9 & 30.3 & 15.8 & 3.3 \\
4.2 .2011 & 243.7 & 14.7 & 10.3 & 3.0 \\
11.2 .2011 & 234.7 & 14.3 & 18.8 & 3.4 \\
18.2 .2011 & 834.3 & 44.2 & 37.6 & 4.3 \\
25.2 .2011 & 1506.2 & 77.9 & 73.8 & 6.3 \\
4.3 .2011 & 294.9 & 17.2 & 9.5 & 2.9 \\
11.3 .2011 & 209.2 & 13.0 & 25.2 & 3.7 \\
18.3 .2011 & 1875.0 & 96.3 & 24.7 & 3.8 \\
25.3 .2011 & 734.3 & 39.2 & 13.1 & 3.1 \\
2.4 .2011 & 1060.9 & 55.5 & 23.6 & 3.6 \\
8.4 .2011 & 949.9 & 50.0 & 60.2 & 5.4 \\
15.4 .2011 & 5078.3 & 256.4 & 79.9 & 6.5 \\
22.4 .2011 & 4245.7 & 214.8 & 90.4 & 7.0 \\
29.4 .2011 & 2185.7 & 111.8 & 51.5 & 5.1 \\
6.5 .2011 & 1912.8 & 98.2 & 42.1 & 4.7 \\
\hline
\end{tabular}

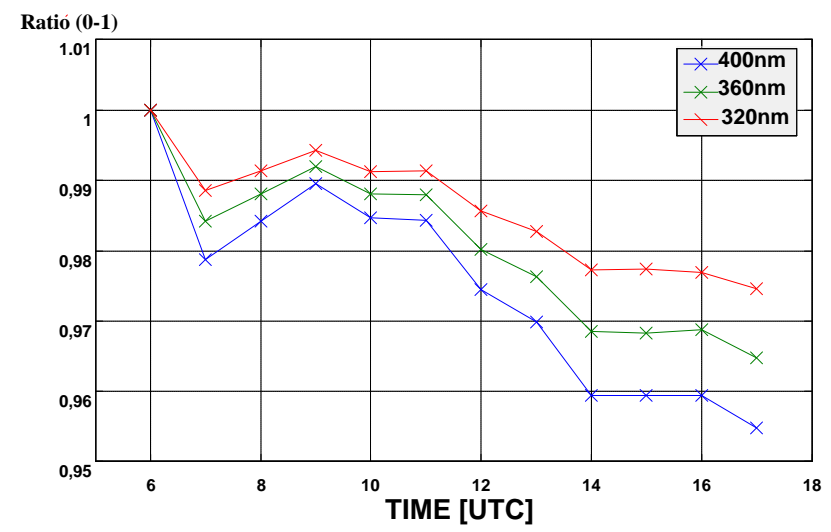

Fig. 8. The ratios (0-1) of modeled irradiances using maximum measured albedo $A_{\max }$ for 22 April, and measured albedo $A$ for the same day.

\subsection{Snow albedo simulations}

The simulated albedo data were calculated using the SNICAR-online version with our measurement results as input data for clear sky (22 April, intensive melting) and diffuse sky (24 April, snow almost melted). To simulate the lowest possible albedo due to the effect of SZA, the value of SZA $=55$ degrees was used, as it was the SZA minimum value for midday on 22 April, at one degree accuracy. We used the following realistic input values (otherwise model default values applied): (a) clear sky case - snow depth of $10 \mathrm{~cm}$, snow grain size radius $1.5 \mathrm{~mm}$, hydrophobic or hydrophilic black carbon of $87 \mathrm{ppb}$; (b) diffuse sky case - snow depth 5, snow 

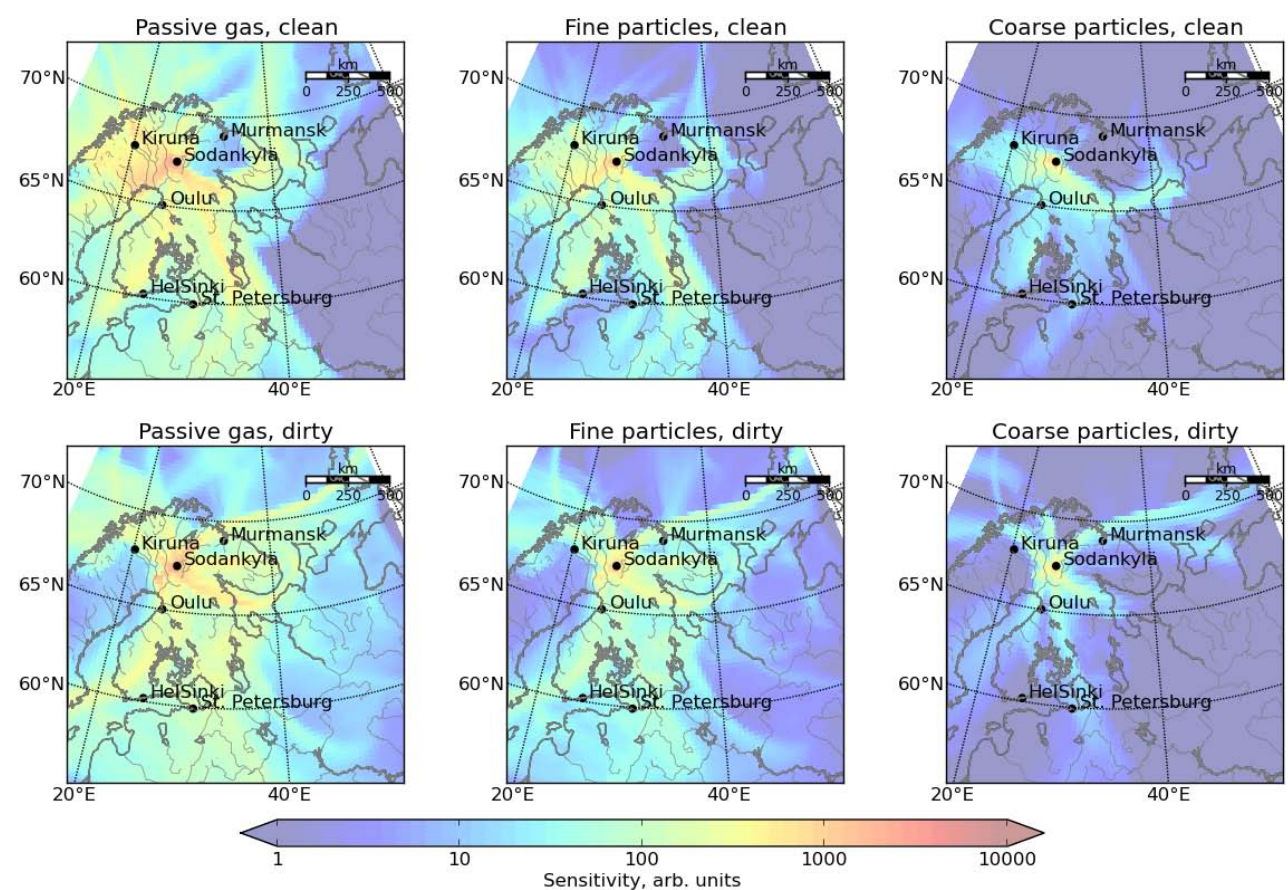

Fig. 9. The footprints for "clean" (upper panels) and "dirty" snowfall (lower panels), on the basis of measured BC mixing ratio in surfacesnow samples, for (i) passive gas (no deposition, decay, etc., left), (ii) fine aerosol (middle), and (iii) coarse aerosol (right).

grain radius $1.5 \mathrm{~mm}$, hydrophobic or hydrophilic black carbon black carbon of $87 \mathrm{ppb}$. A snow density value of 350 $\mathrm{g} \mathrm{m}^{-3}$ was used, following Kuusisto (1984).

From these, the clear sky simulated albedo (Fig. 10) with $10 \mathrm{~cm}$ snow depth and $350 \mathrm{~g} \mathrm{~m}^{-3}$ snow density, produced broadband $A=0.58$ (for both the hydrophobic and hydrophilic BC). The spectral albedo values for wavelengths $300-400 \mathrm{~nm}$ were $A<0.77$ and $A<0.76$, accordingly. In turn, for diffuse sky with $5 \mathrm{~cm}$ snow and $350 \mathrm{~g} \mathrm{~m}^{-3}$ density, the broadband albedo was $A=0.58$ (for both the hydrophobic and hydrophilic BC). The spectral albedo values for wavelengths $300-400 \mathrm{~nm}$ were $A<0.69$, and $A<0.68$, accordingly. These albedo values were based on the snow analysis result of $\mathrm{EC}=87 \mathrm{ppb}$, determined by the thermooptical method (discussed further in Sect. 4.4).

\subsection{Origins of snow impurities}

The attribution of impurities at the surface of melting snow can hardly be done without detailed information on wet and dry deposition and on dynamics of the melting process. However, a general picture on the origins of snow pollution due to long-range transport can be obtained from footprint modeling. Figure 9 shows average footprints for "clean" and "dirty" snow for (i) passive gas, i.e., substance with no deposition, decay, etc.); (ii) fine aerosol that has little deposition; and (iii) coarse aerosol that is subject to intensive wet and dry deposition. The deposition rate controls the extent of a footprint for each species.
The comparison of "clean" and "dirty" patterns clearly reveals a sensitivity area at Kola Peninsula for "dirty" footprint that corresponds to a gap in sensitivity for "clean samples". The gap is most pronounced for fine aerosol particles (middle panels), which are likely to be responsible for the snow pollution. The pattern also agrees with the location of main air pollution sources in the region (Prank et al., 2010): mining and refining industries located at Kola Peninsula.

\section{Discussion}

We have presented spectral and broadband UV and VIS albedo results on seasonal intensively melting snow at Sodankylä, beyond the Arctic Circle. Prior published measurements of albedo for clean snow in this spectral range are $0.97-0.98$ (Fig. 4 of Grenfell et al., 1994) and 0.98-0.99 (Fig. 6 of Hudson et al., 2006); consistent with the extremely small absorption coefficient of ice in this spectral region (Wiscombe and Warren, 1980; Warren et al., 2006; Warren and Brandt, 2008). On the contrary, our albedo results reveal spectral albedo for UV and visible, at wavelengths of $300-560 \mathrm{~nm}$, for SZA 55-70 degrees, and for clear sky and cloudy sky, to be in the range $\sim 0.5-0.7$. These low albedo results are supported by three simultaneous independent albedo measurement setups (one Bentham spectrometer, one SL-501 filter radiometer, one CM-14 albedometer) measuring during the same days at slightly different locations at Sodankylä, as well as by simulated albedo data using SNICAR-online 


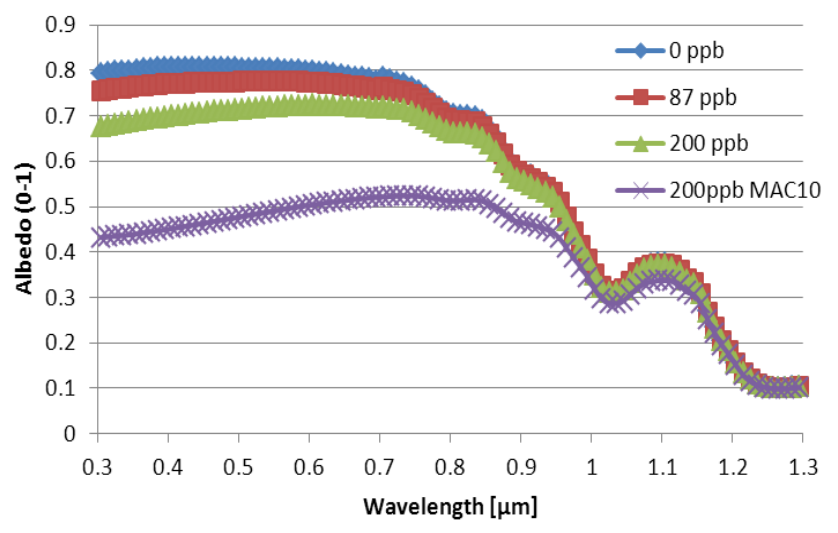

Fig. 10. The SNICAR online simulated snow albedo spectra at 0.3$1.3 \mu \mathrm{m}$ (clear sky at $\mathrm{SZA}=55$ degrees, grain radius $1.5 \mathrm{~mm}$, snow depth $10 \mathrm{~cm}$, snow density $350 \mathrm{~kg} \mathrm{~m}^{-3}$ ) demonstrate that the absorption caused by impurities in snow is greater the shorter the wavelength, compared to clean snow (blue). The EC in snow determined by the thermo-optical method was $87 \mathrm{ppb}$ (red). The snow $\mathrm{BC}$ concentration was assumed to be approx. double the EC concentration determined by the thermo-optical method (green). Introducing a mass absorption coefficient MAC $=10$ produced albedo values close to the lowest measured albedo of $\sim 0.4-0.5$ at UV (purple).

(Flanner et al., 2007) with realistic large snow grains (3 mm diameter) and black carbon ( $87 \mathrm{ppb})$. We have also measured previously UV albedos of $0.5-0.7$ for melting snow at Sodankylä (Meinander et al., 2008). Here, a plausible explanation for our low albedo results is given and discussed.

\subsection{Melting snow and albedo}

First of all, our measurements represent albedo of intensively melting seasonal Arctic snow at Sodankylä, beyond the Arctic Circle. In the beginning of our spectral measurement period (21 April 2009), the melting period had already started. Hence, the albedo values of our work do not represent the albedo values of the snow accumulation period, or new snow cases, when higher albedo values would be expected. Secondly, the maximum grain size diameter was reported to be $3 \mathrm{~mm}$. During the SNORTEX-2009 campaign, the snow grains of various snow pits in Sodankylä have been recorded and stored by macro photography. An example of such a photo is in Meinander et al. (2008, Fig. 4). We have also evidenced the meltwater to increase in the snow surface layer of the spectral albedo field. When snow melts, the effective grain size increases as water surrounds the snow grains. From this it follows that the effective grain size may be even bigger than the observed grain size, already up to several millimeters. Our albedo results on the melting Arctic snow showed a rapid decrease in the albedo as a function of time. Thus, our data showed some indication of possible SZA asymmetric albedo. SZA asymmetry in albedo could also be due to surface features like sastrugi, but in our case the changes in albedo were caused by melting snow, as the forward scattering nature of snow was detected by our measurements with the Sun shining from the southern direction. Hence, the albedo decline was found to dominate over the SZA-dependent albedo signal. The main driver of albedo was intensively melting snow.

\subsection{Supporting measured low albedo}

The low albedo values and the diurnal decrease in albedo, first detected by the spectral data, were supported by the simultaneous broadband measurements. Bentham showed albedo values of $\sim 0.5-0.7$, SL-501 of $\sim 0.4-0.5$, and CM14 of $\sim 0.6-0.75$. The operational field erythemal SL-501 albedo was most often smaller than the albedo values of the primary Bentham field, or of the CM14 at the various SNORTEX sites. However, on 24 April, the spectral values $(A=0.45$ at $330 \mathrm{~nm}$ and $A=0.53$ at $450 \mathrm{~nm})$ and the erythemal UV albedo ( $A=\sim 0.42-0.43$ ) were close to each other. The decrease in erythemal UV albedo within a day was of $\sim 10 \%$, i.e., the same as for the spectral data. Earlier, we have also reported, for the same Sodankylä operational albedo field, erythemally weighted SL-501 radiometer snow UV albedo values of $\sim 0.45-0.69$ during the melt period in 2007 (Table 3 of Meinander et al., 2008). After the melt period, the intensive melt period took place until the ground under snow became visible. During that period the albedos were lower than 0.5 (Fig. 10 of Meinander et al., 2008). Hence, the melt stage (accumulation, melt, intensive melt) of the measurement field affects the measured albedo values. If the various open snowfields are under different stages of melt, it is possible that the snow height and albedo values differ spatially even at close-by locations. Therefore, it is important to have the ancillary data on snow from the same place as the albedo measurement.

The independent broadband CM14 albedo data showed that (a) the broadband albedos were lower than for even aged midwinter snow (measured during SNORTEX experiments), implying that the melt was well under way; (b) the drop in observed albedos during a single field day suggests that snow metamorphism was also very active during this time; and (c) the level of the broadband albedos falled consistently during the four-day period. This behavior is consistent with an increase in effective grain size as the melt enlarges the grain size of the snowpack, and also the thinning snowpack brings more impurities closer to the surface layer where they have a greater effect on the albedo.

\subsection{Optically thin snowpack}

A melting snowpack can become optically thin due to the large grain size, with the result that the low-albedo ground underneath the snow can be "seen". For instance, in Wiscombe and Warren (1980), the 1000 micron grain size would 
correspond to a liquid-equivalent depth, for which the snowpack becomes semi-infinite, to be $50 \mathrm{~cm}$ of old melting snow. In SNICAR-online (Flanner et al., 2007), the underlying ground albedo influences the reflectance of a relatively thin snowpack, but density and effective grain size also determine the influence of underlying ground. In the Arola et al. (2003) work on satellite respectivity versus snow depth (Fig. 1 in their paper), the respectivity of a $0.02 \mathrm{~m}(2 \mathrm{~cm})$ snow depth is marginally different from a $0.1 \mathrm{~m}$ thick snowpack. This gives rise to the question of the importance of the surface layer compared with the layer beneath, when melting snow is considered. Here, the liquid water content of the surface layer $(0 \mathrm{~cm})$ was very low in the afternoon, while the lower layers were more wet. Further, melting leads to radiation entering deeper into the snowpack, where radiation may become effectively trapped if snow is polluted. In our data, UV is relatively more attenuated than visible from 09:00 to 11:00 UTC (Fig. 4), which could indicate absorptive extinction.

\subsection{Impurities in snow}

Moreover, our Sodankylä Arctic Center data in 2009 (Table 3 ), showed that the EC and OC amounts in snow were $87 \mathrm{ppb}$ and $2894 \mathrm{ppb}$, respectively, at the time of the albedo measurements. These impurities have the potential to absorb radiation and thus reduce snow albedo (Warren and Wiscombe, 1980). Yet, according to our experience, as far as snow OC concentrations are concerned, the results may sometimes suffer from contamination by tree debris. On the other hand, however, the results from M. Wang et al. (2013) indicate that in the thermal-optical measurement of EC and OC, elemental carbon and dust generally mix as agglomerates. The aggloremate structure will contribute to an underestimation of EC and $\mathrm{OC}$ during $\mathrm{OC} / \mathrm{EC}$-analysis. This underestimation has been shown to be dependent on the analysis protocol used during OC/EC-analysis (Aamaas et al., 2011; Chow et al., 2001; Reisinger et al., 2008). The NIOSH 5040 protocol has been argued to underestimate the EC content by a factor of two. As a result, we simulated new SNICAR on-line (Flanner et al., 2007) albedo spectra with 200 ppb, i.e., approx. double the $\mathrm{BC}$ amount that was measured using the thermal-optical method. For the clear sky case with $10 \mathrm{~cm}$ snow, and with realistic 200 ppb of hydrophilic BC (Fig. 10) and other parameter values kept the same, the broadband albedo $A=0.55$ and spectral albedo $A(300-400 \mathrm{~nm})=0.68-0.70$ were gained. For the diffuse sky with $5 \mathrm{~cm}$ snow, the broadband albedo was now $A=0.56$, and the spectral albedo $A(300-400 \mathrm{~nm})$ was approx. 0.64 .

The mass absorption coefficient (MAC) default value in SNICAR is MAC $=1$. The MAC of BC is a measure of how much sunlight $\mathrm{BC}$ particles can absorb. According to Bond et al. (2013), the measured values for freshly generated $\mathrm{BC}$ fall within a relatively narrow range of $7.5 \pm 1.2 \mathrm{~m}^{2} \mathrm{~g}^{-1}$ at $550 \mathrm{~nm}$, and the MAC of BC increases by approximately $50 \%$ as $\mathrm{BC}$ becomes internally mixed with other aerosol chemical components. In Hadley and Kirchstetter (2012), their upper limit of simulated spectral albedo corresponds to a BC MAC equal to $7.5 \mathrm{~m}^{2} \mathrm{~g}^{-1}$ at $550 \mathrm{~nm}$, indicated as an appropriate value for freshly emitted BC. Their lower limit corresponds to snow contaminated with $\mathrm{BC}$ that is twice as absorbing (MAC $=15 \mathrm{~m}^{2} \mathrm{~g}^{-1}$ ), indicated as an appropriate value for atmospherically aged $\mathrm{BC}$. Using MAC $=10$ $\mathrm{m}^{2} \mathrm{~g}^{-1}$ together with the $200 \mathrm{ppb}$ hydrophobic BC as input values for the SNICAR simulated albedo, we could match the lowest measured albedos of approx. 0.4 (Fig. 10). For the clear sky case with $10 \mathrm{~cm}$ snow, we then gained albedo values $A=0.43-0.45$ for $300-400 \mathrm{~nm}$, and $A=0.4$ for broadband. Comparing the $87 \mathrm{ppb}$ and the $200 \mathrm{ppb}$ albedo spectra with $\mathrm{MAC}=1$ or MAC $=10$ (Fig. 10), it is obvious that the absorbance due to increased $\mathrm{BC}$ is greater the shorter the wavelength at UV. The effect of absorbing substances on snow albedo has been stated to be the most pronounced: the shorter the wavelength, the bigger the snow grain (Hadley and Kirchtetter, 2012). The same is also true for atmospheric absorbtion by BC (Fig. 9, Voisin et al., 2012).

Black carbon values measured elsewhere in Arctic Scandinavia (Troms $\emptyset$, Norway) are only $\sim 20 \mathrm{ppb}$ in April, although the surface concentration can increase to $60 \mathrm{ppb}$ in late May because of concentration during melting (Table 8 of Doherty et al., 2010). According to our results, the Sodankylä snow samples contained higher impurity concentrations than those in the study by Doherty et al. (2010), and there is a similar increase in impurity concentrations toward the spring. Recently collected snow samples in Arctic Scandinacia show spatial variability in impurities in the snow (Svensson et al., 2013, unpublished data).

Figure 9 shows that the average footprint over cases of clean snow have a very pronounced gap around Murmansk, i.e., a major source of $\mathrm{BC}$ in snow is located in the eastern half of the Kola Peninsula, which agrees quite well with the location of the industrial activities. Hence, our high concentrations of $\mathrm{BC}$ in snow may be due to air masses originating from the Kola Peninsula, Russia, where there are mining and concentrated industry (e.g., Rigina, 2002).

The scientific understanding of the snow organic carbon absorption has started to develop only recently (e.g., McNeill et al., 2012; X. Wang et al., 2013). The main sources of organic carbon to the atmosphere and to snowpack are anthropogenic activities and biomass burning (e.g., Hegg et al., 2010). Hagler et al. (2007) found snow to have a much higher OC to EC ratio $(205: 1)$ than air $(10: 1)$, suggesting that snow is additionally influenced by watersoluble gasphase compounds. France et al. (2012) demonstrated that black carbon alone could not account for all the absorption seen in the Barrow snowpacks, and an additional absorption by Humic Like Substances (HULIS), part of brown carbon, and other chromophores was necessary to explain variation. Voisin et al. (2012) measured HULIS optical properties and reported them to be consistent with aged biomass burning or a possible marine source. McNeill et al. (2012) discussed 
the adsorption and desorption of organic species to and from snow and ice surfaces, and how these processes influence the transport of organic trace gases through snowpack. Moreover, according to Bond et al. (2013), a large fraction of particulate light absorption in Arctic snow (about 30 to $50 \%$ ) is due to non-BC constituents and most of the absorption would be due to light-absorbing organic carbon from biofuel and agricultural or boreal forest burning.

\subsection{About spectral albedo}

The spectral albedo results in Fig. 4 show the decrease of albedo as a function of time (upper panel), and the relative wavelength dependent change (lower panel). From the upper panel we can see the chronological order from highest albedo to lowest albedo (from 09:00 to 17:00 UTC). This decrease in albedo as a function of time is according to the snow grain size (Table 2), changing from $0.25 \mathrm{~mm}$ to $3 \mathrm{~mm}$ diameter grains as a function of time. These results agree with the Wiscombe and Warren (1980) paper, where albedo is expected to decrease with increasing grain size.

The lower panel shows that the spectral change (compared to the 09:00 UTC albedo) is greater the shorter the wavelength (the 11:00 and 13:00 UTC values). This is consistent with the theoretical results of Warren and Wiscombe (1980), which show that absorption due to impurities in snow increases with decreasing wavelength. At 15:00 UTC this spectral behavior seems to disappear and the albedo values are $90 \%$ of those in the morning regardless the wavelength. The SZA is then $\sim 70^{\circ}$. At 17:00 UTC, with SZA $=83^{\circ}$, the spectral behavior turns slightly toward the opposite, the difference from the morning values is larger for VIS than UV. At large zenith angles, the proportion of diffuse radiation is increased as a direct effect, then drastically decreases (e.g., Fig. 8 of Gardner and Sharp, 2010), and the snow albedo is known to decrease as a function of wavelength as the diffuseto-direct radiation ratio increases (Fig. 12 of Wiscombe and Warren, 1980).

\subsection{On the importance of albedo estimates}

A variety of climatological studies including radiative forcing of the planet are dependent on snow albedo assumptions at given seasons. For melting snow seasons these assumptions have to be very carefully implemented in various modeling codes. Also, during snowmelt, the effective surface UV albedo distributions (like those presented in Tanskanen and Manninen, 2007, and Robinson and Kukla, 1984) are expected to move toward smaller values. We may expect that snow height-dependent parameterizations (like in Arola et al., 2003), in turn, might function well during melt time. Winther (1993) has presented the progress of snow albedo for a Norwegian research site, where the albedo decreased as the snow went under a process of metamorphosis. Snow albedo was first determined as a function of temperature index alone.
An improved accuracy of 2-6\% in estimated snow albedo was obtained when solar radiation was included. In several models, such as CAM 3.0 (Collins et al., 2004), ECHAM5 (Roeckner et al., 2003; Roesch and Roeckner, 2006), and in the ECWMF model (ECWMF, 2010), snow albedo decreases with temperature (either linearly or exponentially). The basic parameterizations have the potential to be improved. According to Pedersen and Winther (2005), snow depth-dependent parameterizations perform better during the snowmelt period than temperature-dependent parameterizations. In the paper by Cheng et al. (2006) it has been shown, that in the case that the albedo parameterization is too sensitive to surface temperature, errors in the surface energy and mass balance grow rapidly due to the strong positive feedback between albedo and temperature errors. Furthermore, according to Pirazzini (2008), the representation of the snow and ice albedo for climate and numerical weather prediction models may be one of the most serious oversimplifications, and this may cause large errors in weather prediction and climate simulations. Pirazzini (2008) has presented a simulation experiment with the two-dimensional mesoscale model of the University of Helsinki, Finland, where the old snow albedo of 0.7 was used instead the measured albedo of 0.83 (fresh snow). They concluded that in the case of fresh snow, the use of old snow albedo and thermodynamic values alone caused a delay in the surface cooling and about $3{ }^{\circ} \mathrm{C}$ of error in the surface temperature. Therefore, we might expect that the differences in snow albedo during melt with variation from approx. 0.8 to 0.4 in our results might cause a significant effect, too.

The spectral behavior in snow albedo needs to be considered, especially in cases of wavelength-dependent absorbtance of impurities in the snow. A simple empirical regression converting UVA, UVB, and VIS albedo from one to another may serve as a tool for any application where the albedo is measured at one wavelength range, but the interest lies in another. In our data, when calculating albedo in the visible from albedo at $310 \mathrm{~nm}, R^{2}$ was only 0.6 , indicating that in these data (snow with large snow grains and containing impurities) a linear model was not as good a method as for UVA conversion from UVB $\left(R^{2}=0.97\right)$. Earlier, $\mathrm{Li}$ and Trishchenko (1999) made a study on the development and validation of narrow band to broadband conversion models. According to them, a linear regression (a basic conversion model) between shortwave (SW) albedo $\left(\alpha_{\mathrm{Sw}}\right)$ and VIS albedo $\left(\alpha_{\mathrm{vis}}\right): \alpha_{\mathrm{sw}}=a_{0}+b_{0} \alpha_{v i s}$ that does not require any auxiliary information, has been most widely used. For snow and ice, they gave $a_{0}=10.802$ and $b_{0}=0.725$.

We also found that the albedo of melting snow also decreased by $\sim 10 \%$ as a function of time within a single day, asymmetrically to SZA. In the mornings, the albedo signal was slightly higher than it had been the previous evening, possibly due to frost conditions during the night. Here, the bottom surface $(24 \mathrm{~cm})$ had liquid water, and a temperature profile close to melting conditions $\left(0^{\circ} \mathrm{C}\right)$, suggesting that water vapour from the ground could possibly enter the snow 
surface layer, forming ice crust. The ice crust could then affect the albedo by increasing albedo when icy, and decreasing albedo when melting from the surface. The RT calculations showed that if this $10 \%$ daily melt time asymmetry effect is ignored, an error of $\sim 2-4 \%$ in the calculated clear sky downward irradiance is made for one day. This would mean, e.g., that if using daily satellite-based albedo data for radiative transfer applications, even if satellite and ground albedo were to match perfectly, there would be a remaining error of the mentioned percentages caused by diurnal snow melting.

\subsection{On the error sources}

Finally, the possible error sources in albedo measurements need to be addressed. There are several sources for measurement errors when measuring the solar irradiance. However, many of these errors are eliminated in the albedo results when the division of upward radiation signal to downward radiation signal is performed. This is the case when one properly leveled sensor is used, or when the up and down facing sensors have similar cosine and spectral responses. The error and uncertainty analysis of Bernhard and Seckmeyer (1999) has been our reference in use, in addition to the guidelines of the World Meteorological Organization (WMO). All the FMI-owned irradiance measuring instruments are regularly checked for their angular, spectral and radiometric responses, and the required calibration procedures are carefully performed to produce reliable measurements to fulfill the WMO requirements.

The error caused by the fact that the size of the snow patch used for the spectral measurements extended only $3 \mathrm{~m}$ from the radiometer in one direction has been evaluated in Meinander and Räisänen (2010). According to these calculations, e.g., if the true snow albedo were Asnow $=0.7$ and the environmental albedo Aenv $=0.1$, the measured albedo would be 0.629 , with an error of -0.071 , assuming that the surface is a Lambertian reflector. While this is a significant error, it is not large enough to explain the difference between our albedo results and those measured in, e.g., Grenfell et al. (1994) and Hudson et al. (2006). Moreover, the error estimate provided above is most probably too pessimistic due to the assumption of Lambertian surface. Scattering by snow has a strong forward-scattering component. As the measurements were made for solar azimuths between about 110 and $250^{\circ}$ (south being $180^{\circ}$ ), the Lambertian assumption most probably overestimates the contribution that the area north of the snow patch makes to the measured upwelling irradiance. These calculations have assumed that the surface is flat, and that there are no objects protruding upwards from the surface, so that the downwelling irradiance is horizontally uniform. This is not strictly true, as the snow patch was surrounded by forest. The data analysis was restricted to periods when the sun was high enough $\left(>20^{\circ}\right)$ so that direct sunlight could reach the sensor and the surrounding surface (at least the nearest $10 \mathrm{~m}$ around the sensor) without being blocked by trees. It is, however, possible that some of the diffuse (scattered) radiation was blocked by the trees. This violates the above assumption that the downwelling irradiance $F \downarrow$ is independent of location. Specifically, as the sensor is located $2.5 \mathrm{~m}$ above the surface, the sensor probably experiences slightly less shadowing than the surrounding surface, which means that $F \downarrow$ reaching the sensor may be slightly larger than $F \downarrow$ reaching the surface. This would cause a slight negative bias in the measured albedo, in addition to the negative bias associated with the north edge of the snow patch.

The results presented here are not meant to be representative for the whole melt period, for longer time periods and also not for larger areas, as such. Our major aim with this work was to investigate the spectral behavior of intensively melting snow, and not to repeat the work of Meinander et al. (2008), which deals with issues that require longer-term measurements.

Here, the albedo values detected by the various setups differed slightly from each other. We have evaluated the uncertainty of our SL-501 albedo results (when studying the SZA asymmetry) to be around 2\% (Meinander et al., 2008). The effect of the equipment setup and operator footprints on the CM-14 snow albedo of the observed area have been experimentally confirmed to be no more than 0.02 during the SNORTEX campaigns (A. Riihelä, unpublished data). We explain these differences to be due the fact that the melting phase at a certain time may vary slightly at different places, as evidenced here by the snow height data, too.

If simultaneous albedo values of various close-by open snowfields are at different stages of melt due to local environmental conditions (differences in size of the open area, snow height, etc.), then relative changes in albedo values (e.g., in $\%$ from day to day or morning to afternoon) may offer better information on the changes in albedo during melt than the albedo values alone. This is also supported by the fact that in addition to the snowmelt stage, size of the open field, and snow height, the detected albedo may also be affected by the actual measurement height. Some effect may be also due to small-scale spatial variability of absorbing impurties in the snow (Svensson, 2011). In addition, the calibration factor of the broadband SL-instruments could be improved (as described earlier in Meinander et al., 2008), and different distributions of up- and down-welling radiance might even require different cosine corrections of the two meters. Yet, the most important fact of our results remains: all these measurement results showed albedo values lower than those presented in the literature for clean snow.

\section{Conclusions}

We have measured spectral albedo, as well as ancillary parameters, of seasonal intensively melting snow at boreal region in Sodankylä, Finland $\left(67^{\circ} 22^{\prime} \mathrm{N}, 26^{\circ} 39^{\prime} \mathrm{E}\right)$ beyond the 
Arctic Circle. Our spectral measurements revealed albedo values of $\sim 0.5-0.7$ for ultraviolet and visible range, both under clear sky and variable cloudiness. Our low albedo values were supported by three independent simultaneous albedo measurement setups and simulated albedo data, as well as previous continuous long-term UV albedo data since 2007. During the most intensive snowmelt period of four days, albedo decreased from 0.65 to 0.45 at $330 \mathrm{~nm}$, and from 0.72 to 0.53 at $450 \mathrm{~nm}$. In the literature, the UV and VIS albedo for clean snow are $\sim 0.97-0.99$, consistent with the extremely small absorption coefficient of ice in this spectral region.

We explain the low albedo values to be due to (i) large snow grain sizes up to $\sim 3 \mathrm{~mm}$ in diameter; (ii) meltwater surrounding the grains and increasing the effective grain size; and (iii) absorption caused by impurities in the snow, with concentration of elemental carbon (black carbon) in snow of $87 \mathrm{ppb}$, and organic carbon $2894 \mathrm{ppb}$, at the time of albedo measurements. Due to the thermal-optical method used, the real $\mathrm{BC}$ concentrations could be expected to be approximately double the amounts reported here. Even as such, i.e., without correcting the results, Sodankylä snow samples contained higher impurity concentrations than measured elsewhere in Arctic Scandinavia (Doherty et al., 2010). So far, during the years 2009-2011, the snow EC concentration results have varied between 9-106 ppb, with an average value of $36 \mathrm{ppb}$. When dividing these into clean (snow $\mathrm{EC}<20 \mathrm{ppb})$ and dirty $(\mathrm{EC}>30 \mathrm{ppb})$ cases, the high concentrations of carbon were observed due to air masses originating from Kola Peninsula, Russia, where mining and refining industries are located.

Acknowledgements. We highly appreciate the comments given by Stephen G. Warren and Thomas C. Grenfell (University of Washington, Seattle, WA, USA) during the open discussion of our manuscript. On the basis of their comments, as well as the valuable comments by the three anonymous referees, our manuscript has been greatly improved. The work was supported by the Academy of Finland (projects SAARA and A4). The Sodankylä snow UV albedo and snow impurity studies are included in the Nordic Centre of Excellency Project CRAICC (Cryosphere-Atmosphere Interactions in a Changing Arctic Climate).

Edited by: V.-M. Kerminen

\section{References}

Aamaas, B., Bøggild, C. E., Stordal, F., Berntsen, T., Holmén K., and Ström, J.: Elemental carbon deposition to Svalbard snow from Norwegian settlements and long-range transport, Tellus, 63B, 340-351, doi:10.1111/j.1600-0889.2011.00531.x, 2011.

Arola, A., Kaurola, J., Koskinen, L., Tanskanen, A., Tikkanen, T., Taalas, P., Herman, J. R., Krotkov, N., and Fioletov, V.: A new approach to estimating the albedo for snow-covered sur- faces in the satellite UV method, J. Geophys. Res., 108, 4531, doi:10.1029/2003JD003492, 2003.

Bernhard, G. and Seckmeyer, G.: Uncertainty of measurements of spectral solar UV irradiance, J. Geophys. Res., 104, 1432114345, 1999.

Bernhard, G., Booth, C. R., Ehramjian, J. C., Stone, R., and Dutton, E. G.: Ultraviolet and visible radiation at Barrow, Alaska: Climatology and influencing factors on the basis of version $2 \mathrm{Na}$ tional Science Foundation network data, J. Geophys. Res., 112, D09101, doi:10.1029/2006JD007865, 2007.

Birch, M. E.: Diesel Particulate Matter (as Elemental carbon) Method 5040, in NIOSH Manual of Analytical Methods, National Institute of Occupational Safety and Health, Cincinnati, Ohio, 2003.

Birch, M. E. and Cary, R. A.: Elemental carbon-based method for monitoring occupational exposures to particulate diesel exhaust, Aerosol Sci. Technol., 25, 221-241, 1996.

Blumthaler, M. and Ambach, W.: Solar UVB-Albedo of various Surfaces, Photochem. Photobiol., 48, 85-88, 1988.

Bond, T. C. and Bergstrom, R. W.: Light absorption by carbonaceous particles: An investigative review, Aerosol Sci. Technol., 40, 27-67, doi:10.1080/02786820500421521, 2006.

Bond, T. C., Habib, G., and Bergstrom, R. W.: Limitations in the enhancement of visible light absorption due to mixing state, J. Geophys. Res., 111, D20211, doi:10.1029/2006JD007315, 2006.

Bond, T. C., Doherty, S. J., Fahey, D. W., Forster, P. M., Berntsen, T., DeAngelo, B. J., Flanner, M. G., Ghan, S., Kärcher, B., Koch, D., Kinne, S., Kondo, Y., Quinn, P. K., Sarofim, M. C., Schultz, M. G., Schulz, M., Venkataraman, C., Zhang, H., Zhang, S., Bellouin, N., Guttikunda, S. K., Hopke, P. K., Jacobson, M. Z., Kaiser, J. W., Klimont, Z., Lohmann, U., Schwarz, J. P., Shindell, D., Storelvmo, T., Warren, S. G., and Zender, C. S.: Bounding the role of black carbon in the climate system: A scientific assessment, J. Geophys. Res., doi: 10.1002/jgrd.50171, 2013.

Cheng, B., Vihma, T., Pirazzini, R., and Granskog, M. A.: Modelling of superimposed ice formation during the spring snowmelt period in the Baltic Sea, Ann. Glaciol., 44, 139-146, 2006.

Chow, J. C., Watson, J. G., Crow, D., Lowenthal, D. H., and Merrifield, T.: Comparison of IMPROVE and NIOSH Carbon Measurements. Aerosol Sci. Technol., 34, 23-34, 2001.

Collins, W. D., Rasch, P. J., Boville, B. A., Hack, J. J., McCaa, J. R., Williamson, D. L., Kiehl, J., Briegleb, B., Bitz, C., Lin, S.-J., Zhang, M., and Dai, Y.: Description of the NCAR Community Atmosphere Model (CAM 3.0), NCAR/TN-464+STR NCAR TECHNICAL NOTE June 2004, http://www.cesm.ucar. edu/models/atm-cam/docs/description/node35.html, 2004.

Doherty, S. J., Warren, S. G., Grenfell, T. C., Clarke, A. D., and Brandt, R. E.: Light-absorbing impurities in Arctic snow, Atmos. Chem. Phys., 10, 11647-11680, doi:10.5194/acp-1011647-2010, 2010.

Domine, F., Taillandier, A.-S., and Simpson, W. R.: A parameterization of the specific surface area of snow in models of snowpack evolution, based on 345 measurements, J. Geophys. Res., 112, F02031, doi:10.1029/2006JF000512, 2007.

ECWMF: The European Centre for Medium-Range Weather Forecasts, The ECMWF Integrated Forecast System (IFS), IFS documentation CY25r1, operational on 9 April 2002, Eq. 7.29 at http://www.ecmwf.int/research/ifsdocs/CY25r1/Physics/ Physics-08-05.htm, 2010. 
Fierz, C., Armstrong, R. L., Durand, Y., Etchevers, P., Greene, E., McClung, D. M., Nishimura, K., Satyawali, P. K., and Sokratov, S. A.: The International Classification for Seasonal Snow on the Ground. IHP-VII Technical Documents in Hydrology, no. 83, IACS Contribution no. 1, UNESCO-IHP, Paris, http: //unesdoc.unesco.org/images/0018/001864/186462e.pdf, 2009.

Flanner, M. G., Zender, C. S., Randerson, J. T., and Rasch, P. T.: Present day climate forcing and response from black carbon in snow, J. Geophys. Res., 112, D11202, doi:10.1029/2006JD008003, 2007.

Forsström, S., Ström, J., Pedersen C. A., Isaksson, E., and Gerland, S.: Elemental carbon distribution in Svalbard snow, J. Geophys. Res., 114, D19112, doi:10.1029/2008JD011480, 2009.

France, J. L., Reay, H. J., King, M. D., Voisin, D., Jacobi, H., Beine, H. J., Anastasio, C., MacArthur, A., and Lee-Taylor, J.: Hydroxyl radical and $\mathrm{NO}_{\mathrm{x}}$ production rates, black carbon concentrations and light-absorbing impurities in snow from field measurements of light penetration and nadir reflectivity of on-shore and offshore coastal Alaskan snow, J. Geophys. Res., 117, D00R12, doi:10.1029/2011JD016639, 2012.

Galperin, M.: The approaches to correct computation of airborne pollution advection, in: Problems of ecological Monitoring and Ecosystem Modelling, Gidrometeoizdat, 54-68, 2000.

Gardner, A. S. and Sharp, M. J.: A review of snow and ice albedo and the development of a new physically based broadband albedo parameterization, J. Geophys. Res., 115, F01009, doi:10.1029/2009JF001444, 2010.

Grainger, R. G., Basher, R. E., and McKenzie, R. L.: UV-B Robertson-Berger meter characterization and field calibration, Appl. Optics, 32, 343-349, 1993.

Grenfell, T. C., Warren, S. G., and Mullen, P. C.: Reflection of solar radiation by the Antarctic snow surface at ultraviolet, visible, and near-infrared wavelengths, J. Geophys. Res., 99, 18669-18684, 1994.

Hadley, O. L. and Kirchstetter, T. W.: Black carbon snow albedo reduction, Nature Climate. Change, 2, 437-440, doi:10.1038/nclimate1433, 2012.

Hagler, G. S. W., Bergin, M. H., Smith, E. A., and Dibb, J. E.: A summer time series of particulate carbon in the air and snow at Summit, Greenland, J. Geophys. Res., 112, D21309, doi:10.1029/2007JD008993, 2007.

Hegg, D. A., Warren, S. G., Grenfell, T. C., Doherty, S. J., and Clarke, A. D.: Sources of light-absorbing aerosol in arctic snow and their seasonal variation, Atmos. Chem. Phys., 10, 1092310938, doi:10.5194/acp-10-10923-2010, 2010.

Hudson, S. R., Warren, S. G., Brandt, R. E., Grenfell, T. C., and Six, D.: Spectral bidirectional reflectance of Antarctic snow: Measurements and parameterization, J. Geophys. Res., 111, D18106, doi:10.1029/2006JD007290, 2006.

Kuusisto, E.: Snow accumulation and snowmelt in Finland. Publications of the Water Research Institute, National Board of Waters, Finland, No. 55, 149 pp., 1984.

Kylling, A., Persen, T., Mayer, B., and Svenøe, T.: Determination of an effective spectral surface albedo from ground-based global and direct UV irradiance measurements, J. Geophys. Res., 105, 4949-4959, 2000.

Li, Z. and Trishchenko, A.: A Study toward an Improved Understanding of the Relationship between Visible and Shortwave Measurements, J. Atmos. Ocean. Tech., 16, 347-360, 1999.
Mayer, B. and Kylling, A.: Technical note: The libRadtran software package for radiative transfer calculations - description and examples of use, Atmos. Chem. Phys., 5, 1855-1877, doi:10.5194/acp-5-1855-2005, 2005.

McNeill, V. F., Grannas, A. M., Abbatt, J. P. D., Ammann, M., Ariya, P., Bartels-Rausch, T., Domine, F., Donaldson, D. J., Guzman, M. I., Heger, D., Kahan, T. F., Klán, P., Masclin, S., Toubin, C., and Voisin, D.: Organics in environmental ices: sources, chemistry, and impacts, Atmos. Chem. Phys., 12, 9653-9678, doi:10.5194/acp-12-9653-2012, 2012.

Meinander, O. and Räisänen, P.: Authors' reply to the Anonymous Referee \#1 General Comment \#1: A first estimate for the albedo error associated with the edge, Atmos. Chem. Phys. Discuss., 10, C11474-C11474, http://www.atmos-chem-phys-discuss.net/ 10/C11474/2010/acpd-10-C11474-2010-supplement.pdf, 2010.

Meinander, O., Kontu, A., Lakkala, K., Heikkilä, A., Ylianttila, L., and Toikka, M.: Diurnal variations in the UV albedo of arctic snow, Atmos. Chem. Phys., 8, 6551-6563, doi:10.5194/acp-86551-2008, 2008.

Meinander, O., Wuttke, S., Seckmeyer, G., Kazadzis, S., Lindfors, A., and Kyrö, E.: Solar zenith angle asymmetry cases in polar snow UV albedo, Geophysica, 45, 1-2, 2009.

Meinander, O., Kazadzis, S., Arola, A., Kivi, R., Kontu, A., Suokanerva, H., Aaltonen, V., Manninen, T., Roujean, J.-L., and Hautecoeur, O.: Spectral albedo of arctic snow during intensive melt period, Atmos. Chem. Phys. Discuss., 10, 27075-27098, doi:10.5194/acpd-10-27075-2010, 2010.

Michalsky, J. J., Harrison, L. C., and Berkheiser III, W. E.: Cosine Response Characteristics of Some Radiometric and Photometric Sensors, Solar Energy, 54, 397-402, 1995.

Pedersen, C. A. and Winther, J.-G.: Intercomparison and validation of snow albedo parameterization schemes in climate models, Clim. Dyn., 25, 351-362, 2005.

Pirazzini, R.: Factors controlling the surface energy budget over snow and ice. PhD Thesis. 141 p. Finnish Meteorological Institute Contributions 73, available at: https://oa.doria.fi/bitstream/ handle/10024/42713/factorsc.pdf?sequence=1, 2008.

Prank, M., Sofiev, M., Denier van der Gon, H. A. C., Kaasik, M., Ruuskanen, T. M., and Kukkonen, J.: A refinement of the emission data for Kola Peninsula based on inverse dispersion modelling, Atmos. Chem. Phys., 10, 10849-10865, doi:10.5194/acp10-10849-2010, 2010.

Reisinger, P., Wonashütz, A., Hitzenberger, P., Petzold, A., Bauer, H., Jankowski, N., Puxbaum, H., Chi, X., and Maenhaut, W.: Intercomparison of measurement techniques for black or elemental carbon under urban background conditions in wintertime: Influence of Biomass Combustion, Environ. Sci. Technol., 42, 884889, 2008.

Rigina, O.: Environmental impact assessment of the mining and concentration activities in the Kola Peninsula, Russia by multidate remote sensing, Environ Monit Assess., 75, 11-31, 2002.

Robinson, D. A. and Kukla, G.: Maximum surface albedo of seasonally snow-covered lands in the Northern Hemisphere, J. Clim. Appl. Meteorol., 24, 402-411, 1984.

Roeckner, E., Bäuml, G., Bonaventura, L., Brokopf, R., Esch, M., Giorgetta, M., Hagemann, S., Kirchner, I., Kornblueh, L., Manzini, E., Rhodin, A., U. Schlese, U., Schulzweida U., and Tompkins, A.: The atmospheric general circulation model ECHAM5, Part I, Model description, Report 
349, Max Planck Institute for Meteorology, ISSN 0937 - 1060, http://www.mpimet.mpg.de/fileadmin/models/echam/ mpi_report_349.pdf, 2003.

Roesch, A. and Roeckner, E.: Assessment of Snow Cover and Surface Albedo in the ECHAM5 General Circulation Model, J. Climate, 19, 3828-3843, 2006.

Roujean, J.-L., Manninen, T., Kontu, A., Peltoniemi, J., Hautecoeur, O., Riihelä, A., Lahtinen, P., Siljamo, N., Suokanerva, H., Sukuvaara, T., Kaasalainen, S., Aulamo, O., Aaltonen, V., Thölix, L., Karhu, J., Suomalainen, J., Hakala, T., and Kaartinen, H.: SNORTEX (Snow Reflectance Transition Experiment): Remote sensing measurement of the dynamic properties of the boreal snowforest in support to climate and weather forecast: report of IOP2008, 2009 IEEE International Geoscience \& Remote Sensing Symposium, 12-17 July, Cape Town, South Africa (Paper 1167), 2009.

Roujean, J.-L., Manninen, T., Sukuvaara, T., Peltoniemi, J., Kaasalainen, S., Hautecoeur, O., Lahtinen, P., Riihelä, A., Siljamo, N., Lötjönen, M., Karjalainen, T., Kontu, A., Suokanerva, H., Aulamo, O., Lemmetyinen, J., Suomalainen, J., Hakala, T., Kaartinen, H., Thölix, L., Meinander, O., and Karhu, J.: SNORTEX: Remote sensing measurement of snowmelt in European boreal forest, iLEAPS Newsletter Issue No. 9, April 2010, http://www.ileaps.org/index.php?option=com phocadownload $\backslash$ \&view=category $\backslash \&$ id=3: $\backslash$ \&Itemid=81, 2010.

Seckmeyer, G., Bais, A., Bernhard, G., Blumthaler, M., Booth, R.,S. Lantz, K., and McKenzie, R. L.: Instruments to measure solar ultraviolet radiation, part II: Broadband instruments measuring erythemally weighted solar irradiance, WOM-GAW report, 2005.

Sihvola, A. and Tiuri, M.: Snow Fork for Field Determination of the Density and Wetness Profiles of a Snow Pack, IEEE Transactions on Geoscience and Remote Sensing, 24, 717-721, 1986.

Sofiev, M.: Extended resistance analogy for construction of the vertical diffusion scheme for dispersion models, J. Geophys. Res. Atmos., 107, 4159, doi:10.1029/2001JD001233, 2002.

Sofiev, M., Galperin, M., and Genikhovich, E.: Construction and evaluation of Eulerian dynamic core for the air quality and emergency modeling system SILAM, in: NATO Science for piece and security Serties C: Environmental Security, Air pollution modelling and its application, XIX, edited by: Borrego, C. and Miranda, A. I., Springer, 699-701, 2008.

Svensson, J.: Horizontal meter scale variability of elemental carbon in surface snow, Master's thesis, Dept. of Quaternary Geology and Physical Geography, Stockholm Uni, Stockholm, Sweden, 2011.
Tanskanen, A. and Manninen, T.: Effective UV surface albedo of seasonally snow-covered lands, Atmos. Chem. Phys., 7, 27592764, doi:10.5194/acp-7-2759-2007, 2007.

Toikka, M.: Field tests with the Snow fork in determining the density and wetness profiles of a snow pack, Microwave Signature92, IGLS-Innsbruck, Austria, 1-3 July 1992.

Voisin, D., Jaffrezo, J.-L., Houdier, S., Barret, M., Cozic, J., King, M. D., France, J. L., Reay, H. J., Grannas, A., Kos, G., Ariya, P. A., Beine, H. J., and Domine F.: Carbonaceous species and HUmic LIke Substances (HULIS) in Arctic snowpack during OASIS field campaign in Barrow, J. Geophys. Res., 117, D00R19, doi:10.1029/2011JD016612, 2012.

Wang, M., Xu, B., Zhao, H., Cao, J., Joswiak, D., Wu, G., and Lin, S.: The Influence of Dust on Quantitative Measurements of Black Carbon in Ice and Snow when Using a Thermal Optical Method, Aerosol Sci. Tech., 46, 60-69, doi:10.1080/02786826.2011.605815, 2012.

Wang, X., Doherty, S. J., and Huang, J.: Black carbon and other light-absorbing impurities in snow across Northern China, J. Geophys. Res., doi:10.1029/2012JD018291, in press, 2013.

Warren, S. G. and Brandt, R. E.: Optical constants of ice from the ultraviolet to the microwave: A revised compilation, J. Geophys. Res., 113, D14220, doi:10.1029/2007JD009744, 2008.

Warren, S. G. and Wiscombe, W. J.: A model for the spectral albedo of snow. II: Snow containing atmospheric aerosols, J. Atmos. Sci., 37, 2734-2745, 1980.

Warren, S. G., Brandt, R. E., and Grenfell, T. C.: Visible and nearultraviolet absorptionspectrum of ice from transmission of solar radiation into snow, Appl. Optics, 45, 5320-5334, 2006.

Weller, G.: The tundra microclimate during snow-melt at Barrow, Alaska, Arctic, 25, 291-299, 1972.

Winther, J.-G.: Short- and longterm variability of snow albedo, Nordic Hydrology, 24, 199-212, 1993.

Wiscombe, W. J. and Warren, S. G.: A model for the spectral albedo of snow. I: Pure snow, J. Atmos. Sci., 37, 2712-2733, 1980.

WMO Guide to Meteorological Instruments and methods of Observation, WMO-No. 8 (Seventh Edition,6 August 2008), http://www.wmo.int/pages/prog/www/IMOP/publications/ CIMO-Guide/CIMO_Guide-7th_Edition-2008.html, 2008. 